\title{
Characterization and functional analysis of two novel thermotolerant a-L-arabinofuranosidases belonging to glycoside hydrolase family 51 from Thielavia terrestris and family 62 from Eupenicillium parvum
}

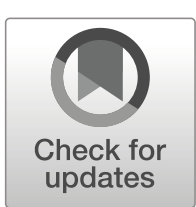

\author{
Liangkun Long $^{1,2}$ (D) $\cdot$ Lu Sun $^{1}$ (D) $\cdot$ Qunying $\operatorname{Lin}^{3}$ (D) Shaojun Ding ${ }^{1}$ (D) $\cdot$ Franz J. St John ${ }^{2}$ (D)
}

Received: 6 February 2020 / Revised: 6 August 2020 / Accepted: 26 August 2020 / Published online: 3 September 2020

(C) The Author(s) 2020

\begin{abstract}
Arabinofuranose substitutions on xylan are known to interfere with enzymatic hydrolysis of this primary hemicellulose. In this work, two novel $\alpha$-L-arabinofuranosidases (ABFs), TtABF51A from Thielavia terrestris and EpABF62C from Eupenicillium parvum, were characterized and functionally analyzed. From sequences analyses, TtABF51A and EpABF62C belong to glycoside hydrolase (GH) families 51 and 62, respectively. Recombinant TtABF51A showed high activity on 4-nitrophenyl- $\alpha$-Larabinofuranoside $(83.39 \mathrm{U} / \mathrm{mg}$ ), low-viscosity wheat arabinoxylan (WAX, 39.66 U/mg), high-viscosity rye arabinoxylan (RAX, $32.24 \mathrm{U} / \mathrm{mg}$ ), and sugarbeet arabinan $(25.69 \mathrm{U} / \mathrm{mg})$, while EpABF62C preferred to degrade arabinoxylan. For EpABF62C, the rate of hydrolysis of RAX $(94.10 \mathrm{U} / \mathrm{mg})$ was 2.1 times that of WAX $(45.46 \mathrm{U} / \mathrm{mg})$. The optimal $\mathrm{pH}$ and reaction temperature for the two enzymes was between 4.0 and 4.5 and $65^{\circ} \mathrm{C}$, respectively. Calcium played an important role in the thermal stability of EpABF62C. TtABF51A and EpABF62C showed the highest thermal stabilities at $\mathrm{pH} 4.5$ or 5.0, respectively. At their optimal $\mathrm{pHs}, \mathrm{TtABF} 51 \mathrm{~A}$ and EpABF62C retained greater than $80 \%$ of their initial activities after incubation at $55^{\circ} \mathrm{C}$ for $96 \mathrm{~h}$ or $144 \mathrm{~h}$, respectively. ${ }^{1} \mathrm{H}$ NMR analysis indicated that the two enzymes selectively removed arabinose linked to C- 3 of mono-substituted xylose residues in WAX. Compared with the singular application of the GH10 xylanase EpXYN1 from E. parvum, co-digestions of WAX including TtABF51A and/or EpABF62C released 2.49, 3.38, and 4.81 times xylose or 3.38, 1.65, and 2.57 times of xylobiose, respectively. Meanwhile, the amount of arabinose released from WAX by TtABF51A with EpXYN1 was 2.11 times the amount with TtABF51A alone.
\end{abstract}

\section{Key points}

- Two novel $\alpha$-L-arabinofuranosidases (ABFs) displayed high thermal stability.

- The thermal stability of GH62 family EpABF62C was dependent on calcium.

- Buffer $p H$ affects the thermal stability of the two ABFs.

- Both ABFs enhance the hydrolysis of WAX by a GH10 xylanase.

Keywords $\alpha$-L-arabinofuranosidase $\cdot$ Thermal stability $\cdot$ Calcium $\cdot$ Synergistic degradation $\cdot$ Filamentous fungi

Liangkun Long and Lu Sun contributed equally to this work.

Electronic supplementary material The online version of this article (https://doi.org/10.1007/s00253-020-10867-7) contains supplementary material, which is available to authorized users.

Shaojun Ding

dshaojun@hotmail.com

Franz J. St John

fjstjohn@gmail.com

1 College of Chemical Engineering, Nanjing Forestry University, Nanjing 210037, China
2 Institute for Microbial and Biochemical Technology, Forest Products Laboratory, USDA Forest Service, One Gifford Pinchot Drive, Madison, WI 53726, USA

3 Nanjing Institute for the Comprehensive Utilization of Wild Plants, Nanjing 211111, China 


\section{Introduction}

Hemicellulose is the second most abundant polysaccharide in the biosphere and is of interest for bioconversion to green chemicals, fuels, biomaterials, functional foods, and pharmaceuticals (Liu et al. 2016; Zhou et al. 2017). Heteroxylans represent the predominant type of hemicellulose found in hardwoods and agricultural crop biomass and is composed of a backbone of $\beta$-1,4-linked xylose residues variably substituted with $\alpha$-L-arabinofuranose, $4-O$-methyl- $\alpha$-D-glucuronic acid, galactose, and acetic acid moieties (Moreira and Filho 2016; Zhou et al. 2017). In the cereal bran xylans, xylose residues may be substituted both with mono- and disubstituted $\alpha$-L-arabinofuranosyl (Araf) residues at O-2 and/ or O-3 positions (McCleary et al. 2015), and the content of arabinose can be as high as 33-45\% depending on the source (Saha 2000). Araf residues also exist in arabinan, gum arabic, and arabinogalactan (Saha 2000). The presence of Araf substitutions enhanced the resistance of xylan to enzymatic hydrolysis (Thakur et al. 2019).

Exo- $\alpha$-L-arabinofuranosidases (ABFs, EC 3.2.1.55) catalyze the hydrolysis of terminal non-reducing $\alpha-1,2-, \alpha-1,3-$, or $\alpha-1,5$-linked Araf residues from arabinose-substituted polysaccharides or shorter oligosaccharides (Thakur et al. 2019; Yang et al. 2015). Based on protein sequence similarities, ABFs have been classified into glycoside hydrolase (GH) families 2, 3, 43, 51, 54, and 62 of the Carbohydrate-Active enZYmes (CAZy) database (http://www.cazy.org/) (Lombard et al. 2014). Members of the GH43 family are active on $\alpha-1,5$ linked L-Ara $f$ oligosaccharides or are specific for $\alpha-1,2$ - and or $\alpha$-1,3-linked Araf from xylan (Mewis et al. 2016), those from GH51 or 54 hydrolyze mono- and di-substituted Araf side chains on arabinoxylan or arabinan (dos Santos et al. 2018), and GH62 family ABFs seem to be specialized in removing mono-substituted Araf residues from arabinoxylans (Wilkens et al. 2017). ABFs of families GH2, 3, 51, and 54 act on the glycosidic linkage by a retaining mechanism, and members of GH43 and 62 families (clan GH-F) display a five-bladed propeller arrangement with an inverting mechanism of hydrolysis (Maehara et al. 2014; Numan and Bhosle 2006; Wang et al. 2014).

Literature indicates that $\mathrm{ABFs}$ are one of the rate-limiting enzymes in xylan degradation (Saha 2000), and their application showed a strong synergistic role with endo-xylanase in degradation of arabinoxylans into arabinose, xylose, and xylooligosaccharides (XOS) (Goncalves et al. 2012; Jia et al. 2016; Ravn et al. 2018). Compared with the individual enzymes, the total amount of released sugar from wheat arabinoxylan was increased to 2.92-fold with simultaneous addition of a GH51 ABF and the GH10 endoxylanase XynBE18 (Yang et al. 2015). Currently, diverse ABFs from both fungal and bacterial sources have been reported, which may provide important information for the understanding of the enzymes (Amore et al. 2012; Bouraoui et al. 2016; Hu et al. 2018; Kaur et al. 2015; Shinozaki et al. 2015; Wilkens et al. 2017; Yang et al. 2015).

Thermotolerant biomass-degrading enzymes usually perform well due to their higher stability and potential for enzyme recycling (Brunecky et al. 2018; Chadha et al. 2019; de Cassia et al. 2015). In addition, elevation of hydrolysis temperature is beneficial to dissolution of substrates and products, enhancement of mass transformation, and reduced risk of microbial contamination (Berka et al. 2011). To date, the reported thermostable ABFs were mainly from thermophilic bacteria. For example, several GH51 family $\mathrm{ABF}$ with high catalytic temperatures (over $60^{\circ} \mathrm{C}$ ) and high thermal stability were isolated from Thermobacillus xylanilyticus, Thermotoga petrophila, or Paenibacillus sp. DG-2 (Debeche et al. 2000; dos Santos et al. 2011; Lee and Lee 2014). Thermophilic fungi and some mesophilic fungi are important producers of thermotolerant enzymes. Thielavia terrestris, which encodes numerous hemicellulolytic enzymes, has a maximum growth temperature over $50{ }^{\circ} \mathrm{C}$ (Berka et al. 2011). The mesophilic fungus Eupenicillium parvum produces diverse hydrolytic enzymes with high temperature optimum and high thermal stabilities, e.g., endoglucanase, $\beta$-glucosidase, and xylanase (Long et al. 2016). In the present study, two thermotolerant ABFs belonging to the fungi T. terrestris (TtABF51A) and E. parvum (EpABF62C) and belonging to $\mathrm{GH}$ families 51 or 62 , respectively, were characterized. The two ABFs were functionally compared regarding the liberation of Araf from different substrates and degradation of wheat arabinoxylan individually, together with a GH10 endoxylanase from E. parvum.

\section{Materials and methods}

\section{Strain, media, and culture conditions}

The filamentous fungus E. parvum 4-14 (CCTCC M2015404) (Long et al. 2016) was maintained on potato dextrose agar (PDA) slant in our laboratory. Escherichia coli strain Tran10 (TransGen, Beijing, China), Pichia pastoris GS115 strain (Invitrogen, Carlsbad, CA, USA), and Trichoderma reesei D-86271 (VTT, Espoo, Finland) were used for plasmid propagation or protein expression, respectively. Mandels' medium was prepared according to the previously reported method (Long et al. 2016) and used for fermentation of $T$. reesei. YPD, BMGY, and BMMY medium were prepared according to the Pichia Expression Kit Instruction Manual (Invitrogen). The recombinant $P$. pastoris strain (named Pp-xyn1) containing the gene EpXyn 1 from E. parvum 4-14 was used to express endo- $\beta$ 1,4-xylanase EpXYN1 of GH 10 family (Long et al. 2018b). 


\section{Gene synthesis, protein expression, and purification of TtABF51A}

A putative GH51 ABF encoding gene from $T$. terrestris NRRL 8126 (TtABF51A) was synthesized according to the published sequence (GenBank XP_003649438.1) and cloned into vector plasmid pPICZ $\alpha \mathrm{A}$ by the Genscript Biotech Corporation (Nanjing, China). To facilitate purification, $6 \times$ his tag was included at the C-terminal of the expressed protein. To express the gene in $T$. reesei, the gene fragment without the signal sequence was PCR amplified using primers Abf51A_f2 and Abf51A_r2 (Supplementary Table S1) and the gene fragment was ligated into plasmid pAg-PTcbh1 (Long et al. 2018c) by Hieff Clone ${ }^{\mathrm{TM}}$ One Step PCR Cloning Kit (Yeasen, Shanghai, China). The recombinant plasmid was introduced into $T$. reesei strain D-86271 by Agrobacterium tumefaciens-mediated transformation method (Long et al. 2018a; Mullins et al. 2001). Fungal transformants were selected on PDA plates containing $100 \mu \mathrm{g} / \mathrm{mL}$ of hygromycin B, identified by PCR amplification with genespecific primers, and then preserved on PDA slant tubes. The plasmid pAg-PTcbh1 was employed as a control in the transformation experiment.

For production of protein TtABF51A, the randomly selected fungal transformants were cultured on PDA plates for sporulation. About $1 \times 10^{8}$ fungal spores were inoculated in a $250-\mathrm{mL}$ flask containing $50 \mathrm{~mL}$ of Mandels' medium with $1 \%$ glucose as carbon source, and grew at $200 \mathrm{rpm}$ and $28{ }^{\circ} \mathrm{C}$ for 2 days on a shaker. Five milliliters of liquid inoculant was transferred into a 2-L flask containing $300 \mathrm{~mL}$ of Mandels' medium with $1 \%(w / v)$ lactose as carbon resource and $60 \mu \mathrm{L}$ antifoam 204 (Sigma, St. Louis, MO, USA), and incubated at $160 \mathrm{rpm}$ and $27^{\circ} \mathrm{C}$ for 5 days. During the fermentation, an appropriate amount of $\mathrm{NaOH}$ solution $(1 \mathrm{M})$ was added into the culture broth to maintain the $\mathrm{pH}$ value at 4.5-5.0. The crude extract of protein TtABF51A was concentrated by ultrafiltration through a $10-\mathrm{kDa}$ cut-off membrane (Amicon 8400; Millipore, Billerica, MA, USA). Then, immobilized metal affinity chromatography (IMAC) was performed by applying the crude protein to Chelating Sepharose Fast Flow (Amersham Biosciences, Uppsala, Sweden) in the $\mathrm{Ni}^{2+}$ form. The protein TtABF51A was eluted with elution buffer ( $\mathrm{pH}$ 7.4) containing $20 \mathrm{mM}$ Tris- $\mathrm{HCl}, 500 \mathrm{mM} \mathrm{NaCl}$, and $300 \mathrm{mM}$ imidazole. After desalting by ultrafiltration (5$\mathrm{kDa}$ cut-off membrane), the protein was further purified by a BioLogic Duo-Flow medium-pressure chromatography system (Bio-Rad, Hercules, CA, USA) equipped with a HiLoad Superdex 200 column, using the gel filtration buffer (GFB) consisting of $25 \mathrm{mM}$ Tris and $150 \mathrm{mM} \mathrm{NaCl}, \mathrm{pH}$ 7.5. This buffer was subsequently used for enzyme storage. After concentration by ultrafiltration, the pure protein was quantified by absorption at $O D_{280 \mathrm{~nm}}$ with a NanoDrop 2000 (Thermo Fisher, Carlsbad, CA, USA) and concentration determined according to the molar extinction coefficient, and stored at $80{ }^{\circ} \mathrm{C}$.

\section{Cloning, protein expression, and purification of EpABF62C}

A gene encoding a putative $\mathrm{ABF}$ which was classified as a $\mathrm{GH}$ family 62 (EpABF62C) was identified in the E. parvum genome by BLAST analysis of fungal transcriptome data (unpublished data). The cDNA fragment of the protein was isolated from the fungus by RT-PCR amplification with specific primers Abf62C_f1 and Abf62C_r1 (Supplementary Table S1). Fungal culture, total RNA extraction, and firststrand cDNA synthesis were conducted by previous methods (Long et al. 2018b). After cloning into the vector pEASYBlunt (Transgene, Beijing, China), the target gene fragment was sequenced by GENEWIZ Biotech. Co. Ltd. (Suzhou, China).

To express the protein in $P$. pastoris cells, the gene was reamplified with primers Abf62C_f2 and Abf62C_r2, and $E c o$ RI and $X b a \mathrm{I}$ restriction fragments were ligated into plasmid pPICZaA. The recombinant plasmid pPIC-GH62C was linearized with enzyme $\mathrm{SacI}$ and introduced into $P$. pastoris GS115 by electroporation with a Gene Pulser II Electroporation System (Bio-Rad, Hercules, CA, USA). Yeast transformants were selected on YPD plates supplemented with $100 \mu \mathrm{g} / \mathrm{mL}$ of Zeocin (Invitrogen). Protein expression was conducted in BMMY medium using $0.8 \%$ methanol as inducer according to the Pichia Expression Kit Instruction Manual (Invitrogen, Carlsbad, CA, USA). Target protein was purified from fermentation supernatant by the same method as described earlier for TtABF51A and analyzed by SDSPAGE.

\section{Activity assay of recombinant protein}

Different substrates including 4-nitrophenyl- $\alpha$-Larabinofuranoside (pNPAraf) (Sigma, St. Louis, MO, USA), low-viscosity wheat arabinoxylan (WAX), high-viscosity rye arabinoxylan (RAX), and sugarbeet arabinan (SBA) (Megazyme, Bray, Ireland) were used to detect the activities of recombinant ABFs. The reaction system consisted of sodium acetate buffer $(0.1 \mathrm{M}, \mathrm{pH} 4.5$ or 5.0$) 50 \mu \mathrm{L}$, pNPAraf $(20 \mathrm{mM}) 5 \mu \mathrm{L}$, enzyme $(20-50 \mathrm{ng} / \mu \mathrm{L}) 10 \mu \mathrm{L}$, and $\mathrm{dH}_{2} \mathrm{O}$ $35 \mu \mathrm{L}$. The mixture was incubated at $70{ }^{\circ} \mathrm{C}$ for $10 \mathrm{~min}$, and $400 \mu \mathrm{L}$ of $\mathrm{NaCO}_{3}(0.2 \mathrm{M})$ was added. The released nitrophenol was detected by measuring the absorbance at $O D_{405 \mathrm{~nm}}$ and calculating the concentration with a standard curve. For the natural substrates, the reaction mixture contained $40 \mu \mathrm{L}$ of the same buffer, $50 \mu \mathrm{L}$ of substrate $(10 \mathrm{mg} / \mathrm{mL})$, and $10 \mu \mathrm{L}$ of enzyme $(25 \mathrm{ng} / \mu \mathrm{L})$. Reaction was performed at 65 or $70{ }^{\circ} \mathrm{C}$ for $20 \mathrm{~min}$, and stopped by incubating at $99{ }^{\circ} \mathrm{C}$ for $10 \mathrm{~min}$. The released reducing sugar was quantified by Somogyi- 
Nelson method (Nelson 1944). Reaction mixtures were diluted 2-fold with addition of $100 \mu \mathrm{L}$ of $\mathrm{dH}_{2} \mathrm{O}$ and mixed with $200 \mu \mathrm{L}$ of the Somogyi reagent. After incubation at $99^{\circ} \mathrm{C}$ for $20 \mathrm{~min}, 200 \mu \mathrm{L}$ of the arsenomolybdate color reagent was mixed with the cooled mixture. This was then diluted with $2 \mathrm{~mL}$ of $\mathrm{dH}_{2} \mathrm{O}$, mixed, and the absorbance at $O D_{540 \mathrm{~nm}}$ measured using a spectrophotometer (Genesys ${ }^{\mathrm{TM}} 10 \mathrm{~S}$ UV-Vis; Thermo Scientific, Waltham, MA, USA). The amount of reducing sugar was calculated according to arabinose standard curve. One unit of ABF activity was defined as the amount of enzyme required to release $1 \mu \mathrm{mol}$ of arabinose or 4nitrophenyl from the corresponding substrate per minute under the reaction conditions.

\section{TLC analysis of hydrolysis product}

Thin-layer chromatography (TLC) was employed to analyze the hydrolysis products of natural substrates by the recombinant enzymes. In a $1.5-\mathrm{mL}$ tube, $50 \mu \mathrm{L}$ of substrate $(10 \mathrm{mg} /$ $\mathrm{mL})$ was mixed with $10 \mu \mathrm{L}$ of enzyme $(50 \mathrm{ng} / \mu \mathrm{L})$ and $40 \mu \mathrm{L}$ of NaAC buffer $(0.1 \mathrm{M}, \mathrm{pH} 4.5)$. The mixtures were incubated at $60{ }^{\circ} \mathrm{C}$ for $20 \mathrm{~min}$ or $4 \mathrm{~h}$. For every sample, $4 \mu \mathrm{L}$ of hydrolysis product was spotted onto a TLC plate (Alltech, Lexington, KY, USA) and the plates were developed with the solvent system chloroform/acetic acid/water (18:21:3, $v / v / v$ ) with two ascensions (St John et al. 2006). The TLC plates were air dried for $30 \mathrm{~min}$ and visualized by spraying with a methanol containing $3 \% \mathrm{H}_{2} \mathrm{SO}_{4}$ and $6.5 \mathrm{mM} \mathrm{N}$-(1naphthyl) ethylendiamine dihydrochloride followed by heating at $110^{\circ} \mathrm{C}$ for $10 \mathrm{~min}$ (Bounias 1980). Arabinose and xylose were used as standards.

\section{Effect of temperature or pH on the enzymatic activity and stability}

The optimum catalysis conditions of recombinant proteins on different substrates were determined in the buffers with different $\mathrm{pH}$ values or under different temperatures in the same buffer with optimized $\mathrm{pH}$. The reaction buffers included glycine- $\mathrm{HCl}$ buffer $(0.1 \mathrm{M}, \mathrm{pH} 2.0-3.5)$, sodium acetate buffer (0.1 M, pH 3.5-6.0), sodium phosphate buffer ( $\mathrm{pH} 6.0$ 8.0), and glycine- $\mathrm{NaOH}$ buffer ( $\mathrm{pH} 8.0-11.0$ ). Relative activity was calculated using the maximum activity which was assayed in the same type of buffer as $100 \%$.

The $\mathrm{pH}$ stability of the enzymes was tested by incubating pure protein $(0.1 \mu \mathrm{g} / \mu \mathrm{L})$ in different buffers $(\mathrm{pH} 2.0-11.0)$ at $4{ }^{\circ} \mathrm{C}$ for $24 \mathrm{~h}$, and the residual enzymatic activities were detected under standard conditions. To evaluate the thermal stabilities of recombinant enzymes, pure proteins $(0.1 \mu \mathrm{g} / \mu \mathrm{L})$ were mixed with different buffers $(\mathrm{pH} 2.0-11.0)$ and incubated at $55{ }^{\circ} \mathrm{C}$ for $24 \mathrm{~h}$, or mixed with $50 \mathrm{mM}$ of sodium acetate buffer ( $\mathrm{pH} 4.5$ or 5.0) and treated under different temperatures up to 1 week. The residual enzymatic activities were assayed using the method described previously. Relative activity (\%) was calculated using the activity of untreated enzyme as $100 \%$.

\section{Effect of metal ions on the activity and stability of recombinant enzymes}

Different metal ions including $\mathrm{Mg}^{2+}\left(\mathrm{MgCl}_{2}\right), \mathrm{Ca}^{2+}\left(\mathrm{CaCl}_{2}\right)$, $\mathrm{Co}^{2+}\left(\mathrm{CoCl}_{2}\right), \mathrm{Ni}^{2+}\left(\mathrm{NiSO}_{4}\right), \mathrm{Fe}^{2+}\left(\mathrm{FeSO}_{4}\right), \mathrm{Mn}^{2+}\left(\mathrm{MnSO}_{4}\right)$, $\mathrm{Zn}^{2+}\left(\mathrm{ZnSO}_{4}\right), \mathrm{Cu}^{2+}\left(\mathrm{CuSO}_{4}\right)$, or EDTA (sodium salt) were added into the reaction system at the final concentration of 1 or $5 \mathrm{mM}$, respectively. Then, the activities of recombinant enzymes were assayed under the standard conditions. Relative activity (\%) was calculated using the activity of untreated enzyme as $100 \%$.

Meanwhile, pure enzymes were treated with EDTA solution to remove divalent metal ions. Purified protein (250$300 \mu \mathrm{L}$ ) was transferred into a Slide-A-Lyzer G2 dialysis cassette (Thermo Scientific) and dialyzed against $50 \mathrm{mM}$ of EDTA in the GFB storage buffer for $20 \mathrm{~h}$, and dialyzed in the same buffer without EDTA for $24 \mathrm{~h}$ (changed the buffer every $8 \mathrm{~h})$ at $4{ }^{\circ} \mathrm{C}$. The treated protein $(0.1 \mu \mathrm{g} / \mu \mathrm{L})$ was incubated with divalent metal ions at a final concentration of $1 \mathrm{mM}$, and subjected to determination of activity or thermal stability as described earlier, using untreated proteins as controls.

\section{Substrate specificity and kinetic parameters}

Specific activities of recombinant proteins on different substrates were measured under optimal conditions. To determine the kinetic parameters of the enzymes, the activities of target proteins were assayed under standard conditions with a substrate concentration response curve. With these data, the $K_{\mathrm{m}}$ and $V_{\max }$ values were calculated by the software GraphPad Prism 7.04 using nonlinear regression (https://www. graphpad.com/).

\section{${ }^{1} \mathrm{H}$ NMR analysis of modes of actions of ABFs toward arabinoxylan}

The modes of actions of TtABF51A and EpABF62C toward wheat arabinoxylan were evaluated using one-dimensional ${ }^{1} \mathrm{H}$ nuclear magnetic resonance (NMR) spectra as previously described (Wang et al. 2014; Sarch et al. 2019). In a 2-mL tube, $300 \mu \mathrm{L}$ of WAX $(20 \mathrm{mg} / \mathrm{mL})$ was mixed with $10 \mu \mathrm{L}$ of TtGH51A or EpGH62C $(0.3 \mu \mathrm{g} / \mu \mathrm{L})$ and $290 \mu \mathrm{L}$ of NaAC buffer $(0.1 \mathrm{M}, \mathrm{pH} 4.5)$. After incubation at $55^{\circ} \mathrm{C}$ for $24 \mathrm{~h}$, the enzymatic reactions were quenched by boiling for $10 \mathrm{~min}$. Following each enzyme treatment, the mixtures were precipitated by addition of ethanol to approximately $66 \%$ with incubation at $4{ }^{\circ} \mathrm{C}$ for $3 \mathrm{~h}$ and then separated by centrifugation at $15,000 \times \mathrm{g}$ for $10 \mathrm{~min}$. The pellet was suspended in $0.6 \mathrm{~mL}$ of $\mathrm{ddH}_{2} \mathrm{O}$ and again precipitated with ethanol by the same 
method. To solubilize the xylan that precipitated upon releasing the L-Araf substituents by the enzyme treatment, the pellet was suspended in $0.6 \mathrm{~mL}$ of $10 \mathrm{mM} \mathrm{NaAC}$ buffer (pH 5.0) and digested by $2 \mu \mathrm{g}$ of the endoxylanase EpXYN3 of GH1 1 family (Long et al. 2018b) at $45{ }^{\circ} \mathrm{C}$ for 2 days. The reaction mixtures were treated at $100{ }^{\circ} \mathrm{C}$ for $10 \mathrm{~min}$ and then lyophilized and dissolved in $0.6 \mathrm{~mL}$ of $\mathrm{D}_{2} \mathrm{O}$ two times. ${ }^{1} \mathrm{H}$ NMR spectra were obtained at $25^{\circ} \mathrm{C}$ in 5.0-mm NMR tubes (Norell) by using an AVANCE III HD 600-MHz spectrometer with a scan number of 16 and a relaxation delay of $10 \mathrm{~s}$. The data were recorded by using Topspin 3.5 (Bruker, Shanghai, China) and analyzed with MestReNova 14.0.0 software (Mestrelab Research, Escondido, CA) as described previously (Wang et al. 2014; Sarch et al. 2019). At the same time, the ratios of mono- and di-substituted $\alpha$-1,2- or $\alpha$-1,3-L-Araf on WAX and RAX were compared by using the same ${ }^{1} \mathrm{H}$ NMR analysis, except that the substrates were not treated with the ABFs.

\section{Synergistic degradation of arabinoxylan with ABFs and xylanase}

Xylanase EpXYN1 was prepared by fermentation of P. pastoris strain Pp-xyn1 according to the previous method (Long et al. 2018b). In a 2-mL centrifuge tube, $50 \mu \mathrm{L}$ of substrate $(10 \mathrm{mg} / \mathrm{mL})$ and $100 \mu \mathrm{L}$ of sodium acetate solution $(100 \mathrm{mM}, \mathrm{pH} 4.5)$ were mixed with individual enzyme or combinative enzymes $(0.5 \mu \mathrm{g}$ of each enzyme), and increased the reaction volume to $200 \mu \mathrm{L}$ by the addition of distilled water. The reaction mixture was incubated in a water bath with $55^{\circ} \mathrm{C}$ for $24 \mathrm{~h}$, and the released reducing sugars were quantified by Somogyi-Nelson test (Nelson 1944) or HPLC analysis. For HPLC analysis, the reactions were precipitated with $80 \%$ ethanol on ice for $40 \mathrm{~min}$ to remove the remaining undigested polysaccharide. After centrifugation at $9000 \times g$ for $10 \mathrm{~min}$, the supernatant was dried using a Savant SpeedVac ${ }^{\circledR}$ System (Thermo Scientific) and re-dissolved in ultra-pure water. The released xylose, arabinose, and xylooligosaccharide were quantified by an Agilent Infinity HPLC system (Agilent Technologies, Santa Clara, CA, USA) equipped with a SHODEX Sugar SH 1821 column (SHODEX, Shanghai, China) with $0.01 \mathrm{~N}$ of $\mathrm{H}_{2} \mathrm{SO}_{4}$ as eluent at a flow rate of $0.8 \mathrm{~mL} / \mathrm{min}$ and a column temperature of $60{ }^{\circ} \mathrm{C}$. The degree of synergy is defined as the ratio of the total amount of liberated sugars resulting from the combined enzyme treatment to the sum of the sugars released by the xylanase or ABFs used separately (Yang et al. 2015).

\section{Bioinformatic analysis}

The amino acid sequences of target proteins were subjected to the online BLAST analysis (https://blast.ncbi.nlm.nih.gov/ Blast.cgi). Prediction of signal peptide, theoretical molecular weight (MW), and $\mathrm{p} I$ were conducted by SignalP-5.0 (http:// www.cbs.dtu.dk/services/SignalP/) or ProtParam tool (https:// web.expasy.org/protparam/), respectively. After removing signal sequences, the two protein sequences with their close relatives from GenBank were aligned using ClustalX2 (Larkin et al. 2007), and a phylogenetic tree was constructed using the neighbor-joining method with the Poisson model and 1000bootstrap test iterations using Mega 7 software (Kumar et al. 2018). The three-dimensional (3D) model structures of TtABF51A and EpABF62C were predicted using the online I-TASSER server (https://zhanglab.ccmb.me d.umich.edu/ITASSER/) (Yang and Zhang 2015).

\section{Results}

\section{Molecular characteristics of TtABF51A and EpABF62C}

The full length of cDNA fragments encoding the proteins TtABF51A (640 amino acids, aa) and EpABF62C (328 aa) were 1920 and 984 bp (GenBank MN855573), respectively. A 20 aa or 26 aa signal peptide was predicted at the $\mathrm{N}$ terminus of protein TtABF51A or EpABF62C, respectively. The $\mathrm{N}$ terminus of TtABF51A contains a predicted carbohydrate-binding module (CBM) (aa positions 56192) belonging to CBM family 4_9. As determined using the ProtParam tool, the theoretical $\mathrm{MW}$ and $\mathrm{p} I$ were $67.8 \mathrm{kDa}$ and 5.71 for TtABF51A, or $32.8 \mathrm{kDa}$ and 5.89 for EpABF62C. TtABF51A has its greatest homology to an uncharacterized GH51 protein (GenBank XP_003658814.4) from Thermothelomyces thermophilus with approximately $71 \%$ identity and shares $53 \%$ identity with a characterized GH51 ABF (GenBank BAG71680.1) from Penicillium chrysogenum (Sakamoto et al. 2013; Shinozaki et al. 2015). EpABF62C showed 73\% identity with a characterized ABF (GenBank CAA16189) belonging to GH62 from the bacterium Streptomyces coelicolor (Maehara et al. 2014). The constructed phylogenetic trees indicated that TtABF51A and EpABF62C were affiliated with the ABFs belonging to GH51 or 62 family (62_2 subfamily), respectively (Fig. 1a, b).

Conserved residues of ABFs belonging to GH51 (e.g., catalytic residues Glu356 and Glu432) or GH62 (e.g., "SHG" motif) families were found in the sequences of TtABF51A or EpABF62C, respectively (Supplementary Fig. S1). The predicted protein structure of TtABF51A consists of a CBM domain, a $(\beta / \alpha)_{8}$-barrel, and a $\beta$-sandwich domain (Supplementary Fig. S2) with an overall structural fold similar to the dual-domain glycoside hydrolase families 30,39 , and 44 (St John et al. 2010), and has a high structural similarity (ITASSER TM score 0.707 ) to the structure of the family GH51 ABF (PDB 1qw9A) from Geobacillus stearothermophilus T6 (Hovel et al. 2003). In the predicted structure model of 
Fig. 1 Phylogenetic tree analysis of proteins TtABF51A (a) and EpABF62C (b) with the arabinofuranosidases belonging to GH51 or GH62 families. Mature protein sequences were used to construct the phylogenetic tree. The trees were constructed with MEGA 7.0 using neighborjoining method under the Poisson model. Numbers on branches indicate bootstrap values from 1000 replications. * indicates uncharacterized protein (a)

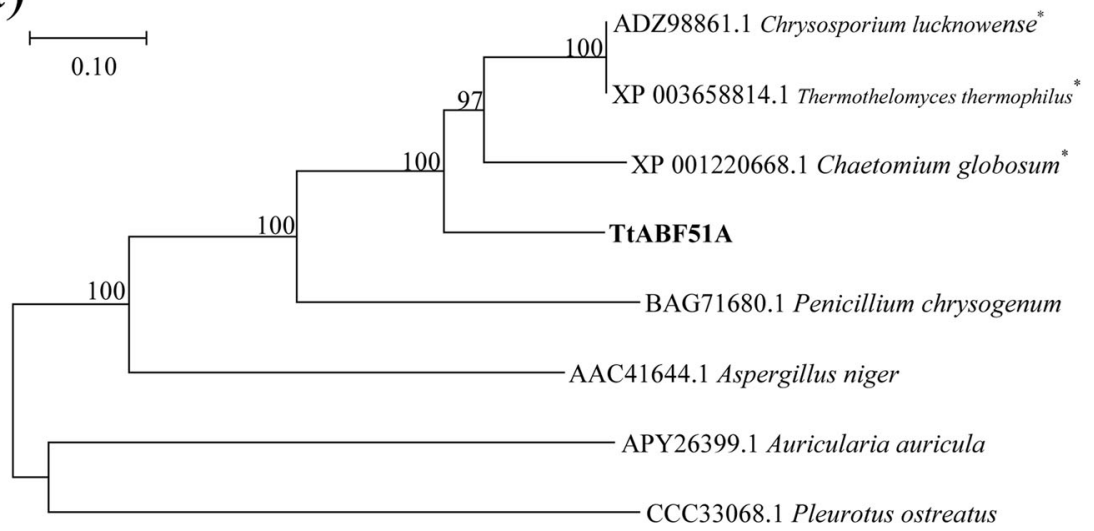

(b)

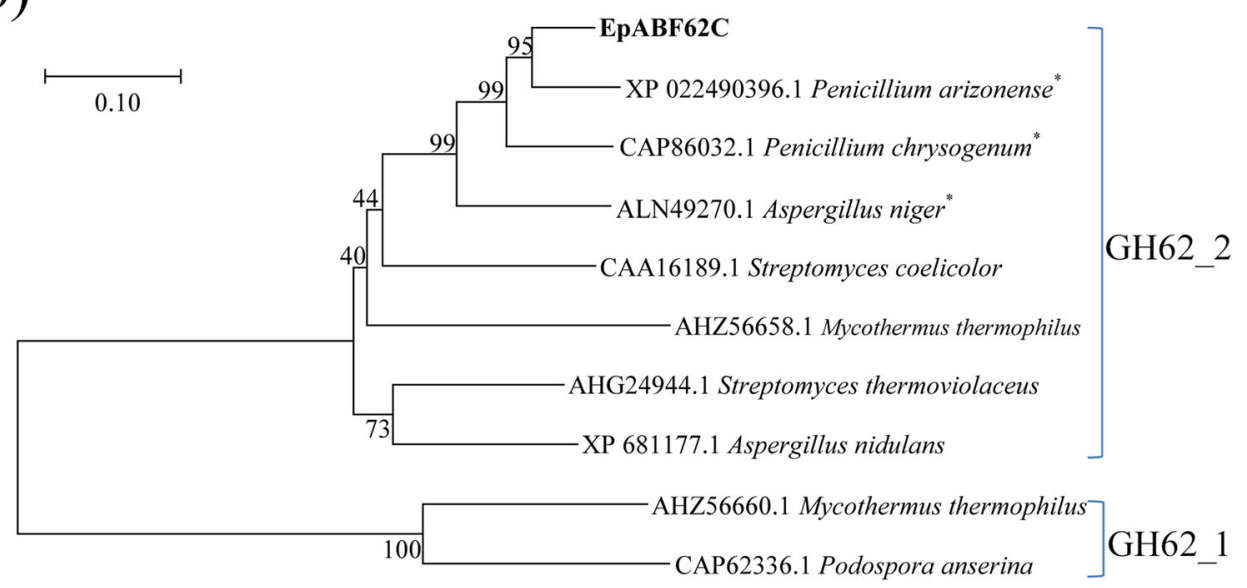

EpABF62C, the common 5-fold $\beta$-propeller structure and the conservative catalytic triad (amino acid residues D54, D162, and E214) were observed (Supplementary Fig. S2). The structure is highly similar (TM score 0.993 ) to the structure of an ABF of GH62 family (PDB 5ubjA) from Aspergillus nidulans (Contesini et al. 2017).

\section{Expression and purification of recombinant proteins}

Proteins TtABF51A and EpABF62C were successfully produced by fermentation of the recombinant $T$. reesei or $P$. pastoris strains, respectively. Under the expression conditions, $13.5 \mu \mathrm{g} / \mathrm{mL}$ of TtABF51A and $149.4 \mu \mathrm{g} / \mathrm{mL}$ of EpABF62C were purified from the crude fermentation broths. On the SDS-PAGE gel, the apparent MW of recombinant TtABF51A was close to $80 \mathrm{kDa}$, which is higher than the theoretical value $(68.6 \mathrm{kDa})$. This difference may be due to three N-glycosylated positions (N46, N207, and N516) that were predicted in the mature protein of TtABF51A by the online analysis (http://www.cbs.dtu.dk/services/NetNGlyc/). For EpABF62C, the apparent MW by SDS-PAGE was in agreement with the theoretical MW value (Fig. 2).

\section{Biochemical characterization of recombinant proteins}

\section{Hydrolytic product and optimal catalytic conditions}

TLC analysis indicated that only arabinose was released from WAX, RAX, or SBA by the two proteins, and TtABF51A showed higher activity than EpABF62C on SBA (Supplementary Fig. S3). In hydrolysis of pNPAraf, TtABF51A showed the highest activity at $\mathrm{pH} 5.0$ and $70{ }^{\circ} \mathrm{C}$ (Fig. 3a, b) while the optimal hydrolysis conditions for the natural substrate WAX was at $\mathrm{pH} 4.5$ and $65^{\circ} \mathrm{C}$ (Fig. 3c, d). Using RAX or SBA as substrate, TtABF51A displayed the best activity at $\mathrm{pH} 4.0$ and $65^{\circ} \mathrm{C}$, respectively (Supplementary Fig. S4a-d). The best $\mathrm{pH}$ and temperature for the activity of EpABF62C was 4.5 and $65{ }^{\circ} \mathrm{C}$ toward WAX (Fig. 3e, f) or RAX (Supplementary Fig. S4e and f).

Effect of metal ions on the enzymatic activities and thermal stabilities:

The activity of TtABF51A was inhibited by $\mathrm{Cu}^{2+}, \mathrm{Zn}^{2+}$, $\mathrm{Mn}^{2+}, \mathrm{Fe}^{2+}, \mathrm{Co}^{2+}$, and $\mathrm{Ni}^{2+}$ to various degrees (Fig. 4a). This enzyme lost 52 or $85 \%$ activity in the presence of $\mathrm{Zn}^{2+}$ or $\mathrm{Cu}^{2+}$, respectively. Among these metal ions, $\mathrm{Cu}^{2+}, \mathrm{Zn}^{2+}$, $\mathrm{Mn}^{2+}$, and $\mathrm{Fe}^{2+}$ showed inhibitory effect on EpABF62C. 


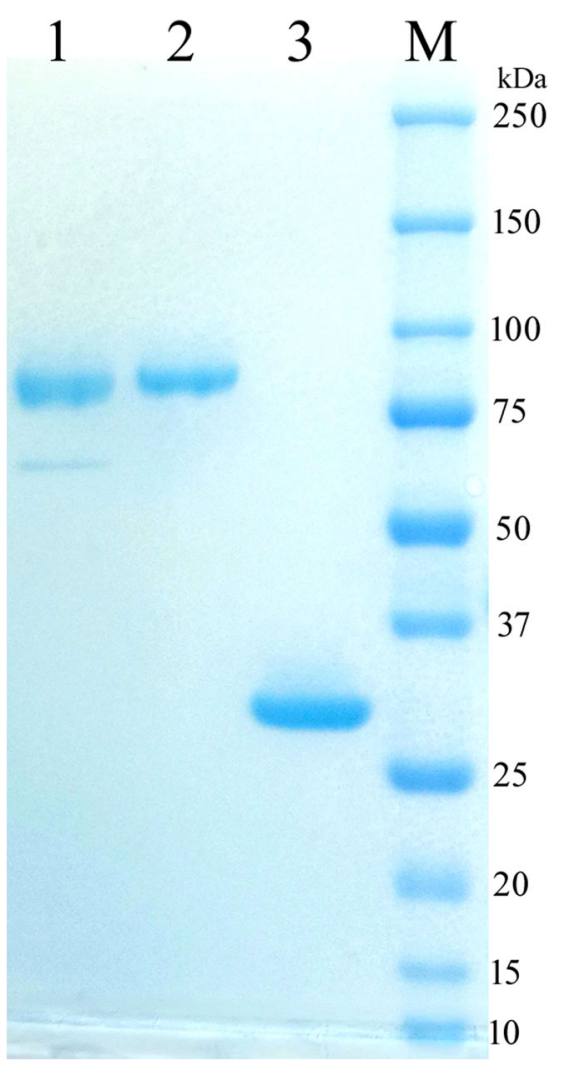

Fig. 2 Analysis of recombinant proteins by SDS-PAGE. Lane 1, protein TtABF51A following purification by $\mathrm{Ni}^{2+}$ IMAC; lane 2, protein TtABF51A after second purification with chromatography system; lane 3 , pure EpABF62C following $\mathrm{Ni}^{2+}$ IMAC; $M$, protein marker. About $6-$ $8 \mu \mathrm{g}$ of protein was loaded in each lane for electrophoresis on a $4-15 \%$ gradient SDS-PAGE gel

The addition of $\mathrm{Mg}^{2+}, \mathrm{Co}^{2+}$, or $\mathrm{Ni}^{2+}$ did not change the enzymatic activity. Meanwhile, EDTA did not change the activity of TtABF51A; however, EpAbf62C activity decreased 15\% in the presence of $5 \mathrm{mM}$ EDTA (Fig. 4b).

Continued incubation of EpABF62C in $1 \mathrm{mM}$ of EDTA at $55^{\circ} \mathrm{C}$ led to eventual loss of detectable activity (Fig. 5a). In a separate study, EDTA was used under mild conditions to remove excess metal ions, and $\mathrm{Mg}^{2+}, \mathrm{Co}^{2+}, \mathrm{Ni}^{2+}$, or $\mathrm{Ca}^{2+}$ were separately tested to determine which has a role in protein stability. EpABF62C was incubated at $60{ }^{\circ} \mathrm{C}$ for 0.5 to $24 \mathrm{~h}$ in the presence of the additional metal ions. After $0.5 \mathrm{~h}$ of incubation, the enzyme maintained high (over $84 \%$ ) activity for all the cation treatments. During extended incubation times, the activity of EpABF62C remained high only in the presence of calcium ion (Fig. 5b). These results indicated that calcium plays a critical role in the thermal stability of EpABF62C.

\section{Effects of $\mathrm{pH}$ on thermal stability of the recombinant enzymes}

Both TtABF51A and EpABF62C maintained over 90\% of their activities following incubation in buffers from $\mathrm{pH} 2.0$ to 11.0 at $4{ }^{\circ} \mathrm{C}$ for $24 \mathrm{~h}$ (Fig. 6a). A similar study performed at $55{ }^{\circ} \mathrm{C}$ resulted in activity loss of both enzymes with reaction optimal $\mathrm{pH}$ divergence. For TtABF51A, the enzyme kept the highest (over 90\%) level of activity in the buffers with $\mathrm{pH} 4.0$ or 4.5 , and treatment with $\mathrm{pH} 2.0$ or over 8.0 led to the loss of the full activity of the enzyme. EpABF62C maintained maximum activity after treatment at $\mathrm{pH} 5.0$ or 5.5 , and quickly decreased the residual activity with higher or lower $\mathrm{pH}$ conditions (Fig. 6b). The thermal stabilities of the two enzymes were strongly affected by environmental $\mathrm{pH}$ value.

The thermal stabilities of the two enzymes were further evaluated under their respective optimum protein stability $\mathrm{pH}$ condition over time at $50,55,60$, and $65^{\circ} \mathrm{C}$, respectively. Both TtABF51A and EpAbf62C maintained 80 and 90\% of their respective activities following $168 \mathrm{~h}$ of incubation at $50{ }^{\circ} \mathrm{C}$. Both enzymes also performed well at $55^{\circ} \mathrm{C}$ with TtABF51A maintaining over $80 \%$ of its initial activity following $96 \mathrm{~h}$ and EpABF62C following $144 \mathrm{~h}$. At 60 or $65^{\circ} \mathrm{C}$, the two enzymes lost their activities relatively quickly (Fig. 7a, b).

\section{Specific activities and kinetic parameters}

The kinetic parameters of recombinant enzymes toward different substrates were calculated according to the generated substrate concentration kinetic curves (Table 1, Supplementary Fig. S5). As can be seen from Table 1, TtABF51A showed broad activity on the tested substrates including pNPAraf $(83.39 \mathrm{U} / \mathrm{mg})$, WAX $(39.66 \mathrm{U} / \mathrm{mg})$, RAX (32.24 U/mg), and SBA (25.69 U/mg). The enzyme displayed a higher substrate affinity (lower $K_{\mathrm{m}}$ ) on RAX rather than on WAX. At a low substrate concentration (below $4 \mathrm{mg} / \mathrm{mL}$ ), TtABF51A showed a higher activity on RAX than that on WAX (Supplementary Fig. S6). Enzyme EpABF62C displayed high activity on RAX (94.10 U/mg) and WAX (45.46 U/mg) but not pNPAraf or arabinans. Calcium slightly affected the specific activity and kinetic parameters of the enzyme while using WAX as substrate.

\section{Regioselectivity of ABFs toward arabinoxylan}

${ }^{1} \mathrm{H}$ NMR analysis indicated that WAX contains three types of $\alpha$-L-Araf substitutions with the corresponding signal, including $\alpha-1,3-\mathrm{L}-$ Araf linked to C-3 of mono-substituted xylose, and $\alpha-1,3-\mathrm{L}-A r a f$ and $\alpha-1,2-\mathrm{L}-A r a f$ linked to $\mathrm{C}-3$ and C-2 of di-substituted xylose with chemical shifts at 5.41, 5.28, and $5.23 \mathrm{ppm}$, respectively (Fig. 8). The signals of chemical shifts were in agreement with the literature data (Pitkanen et al. 2009; Sakamoto et al. 2011; Wang et al. 2014). Treatment with TtABF51A or EpAbf62C resulted in the disappearance of the signal at $5.41 \mathrm{ppm}$ but not the signals at 5.28 and 5.23 ppm (Fig. 8a, b), indicating the two enzymes selectively 
(a)

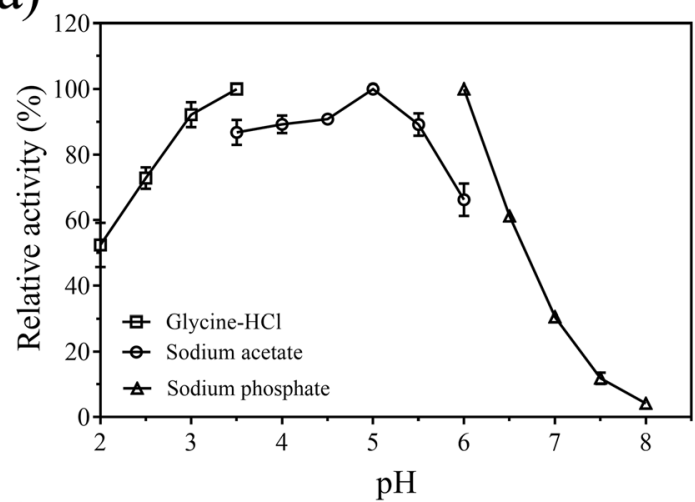

(c)

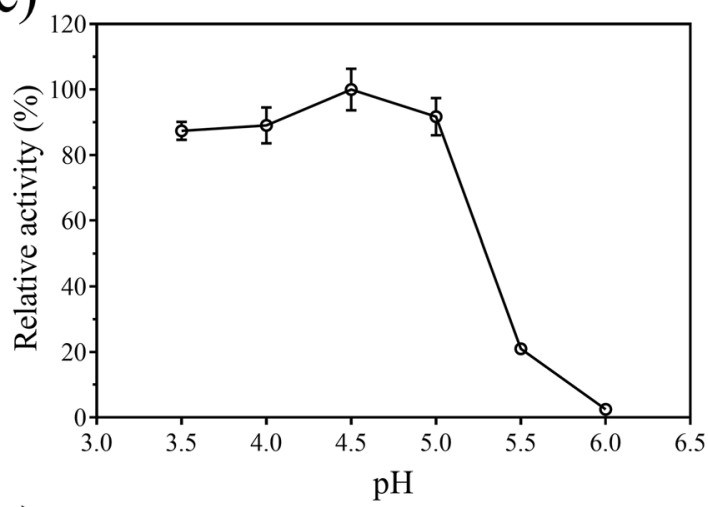

(e)

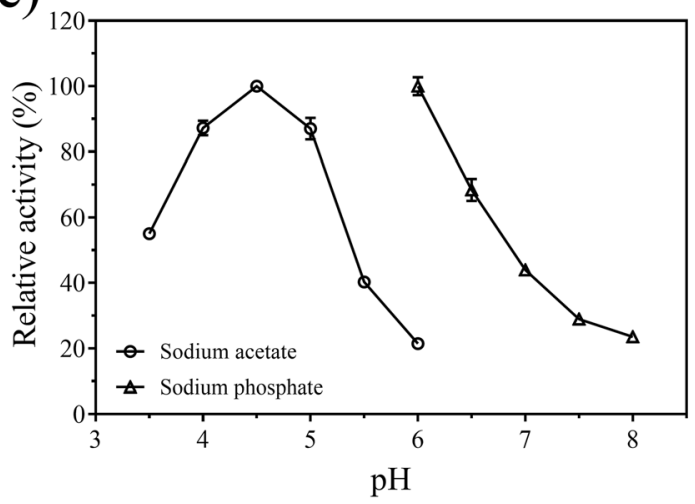

Fig. 3 Optimal pHs or temperatures of the recombinant enzymes on synthetic or natural substrates. a, b Effect of $\mathrm{pH}$ or temperature on the activity of enzyme TtABF51A toward pNPAraf. c, $\mathbf{d}$ Effect of $\mathrm{pH}$ or temperature on the activity of enzyme TtABF51A toward wheat arabinoxylan. $\mathbf{e}, \mathbf{f}$ Effect of $\mathrm{pH}$ or temperature on the activity of enzyme

acted on the singly substituted $\alpha-1,3-\mathrm{L}-\mathrm{Ara} f$ in the arabinoxylan. This NMR approach was further utilized to confirm previously reported differences in the nature of Araf substitution between WAX and RAX. The substrate RAX contains the same three types of $\alpha$-L-Araf substitutions, but the relative intensity (\%) of $\alpha-1,3-\mathrm{L}-\mathrm{Ara} f$ in this arabinoxylan was about two times of that in WAX (Supplementary Fig. S7). RAX was not used for the regioselectivity analysis of TtABF51A or EpAbf62C due to the severe precipitation of the substrate after treating with the two ABFs. (b)

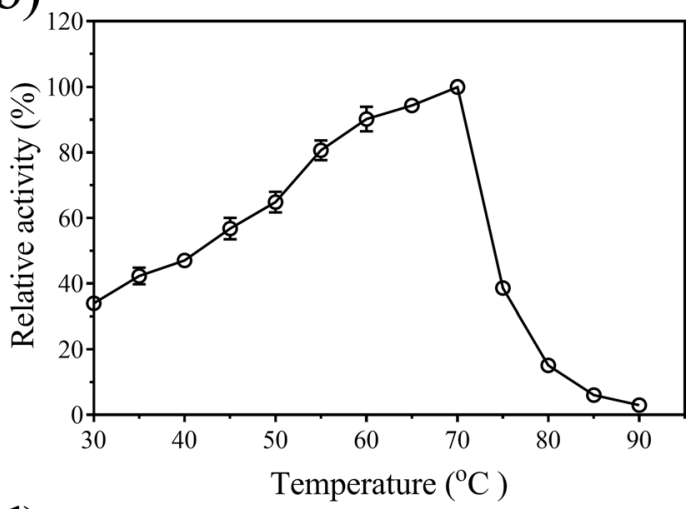

(d)

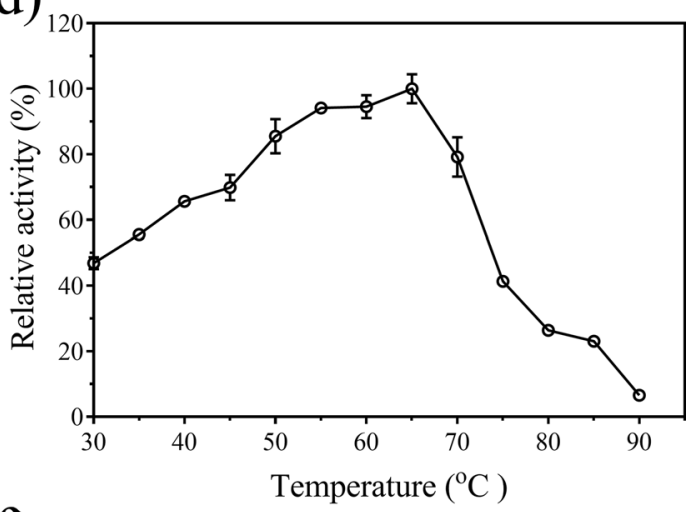

(f)

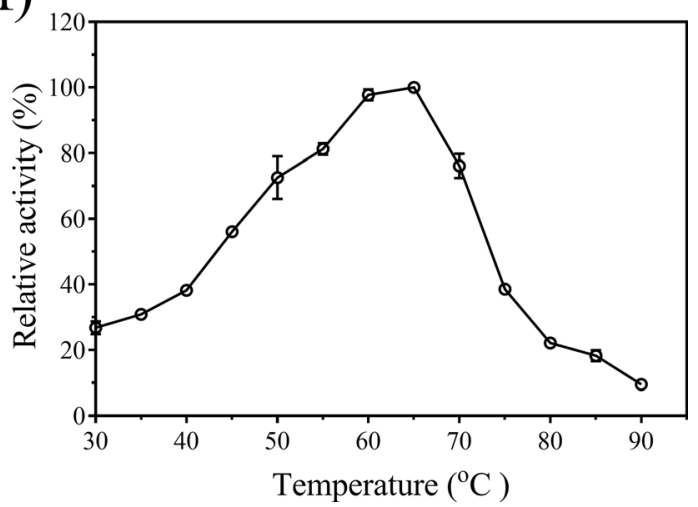

EpABF62C toward wheat arabinoxylan. Except as indicated, enzymatic activities were assayed at $70{ }^{\circ} \mathrm{C}$ (a) or $65^{\circ} \mathrm{C}(\mathbf{c}, \mathbf{e})$, and in sodium acetate buffer with pH 5.0 (b) or 4.5 (d, f). Relative activity was calculated using the maximum activity as $100 \%$. Error bars represent SDs from three independent assays

\section{Improvement of WAX degradation by synergistic role of xylanase and ABFs}

The hydrolytic products of WAX by the individual or the combined enzymes were quantified by HPLC analysis (Table 2). Only arabinose was liberated from the substrate under the action of enzymes TtABF51A or EpABF62C. The amount of released xylose or xylobiose from WAX by the combination of TtABF51A and EpXYN1 was 2.49 times or 3.38 times of that by EpXYN1 alone, respectively. 
(a)

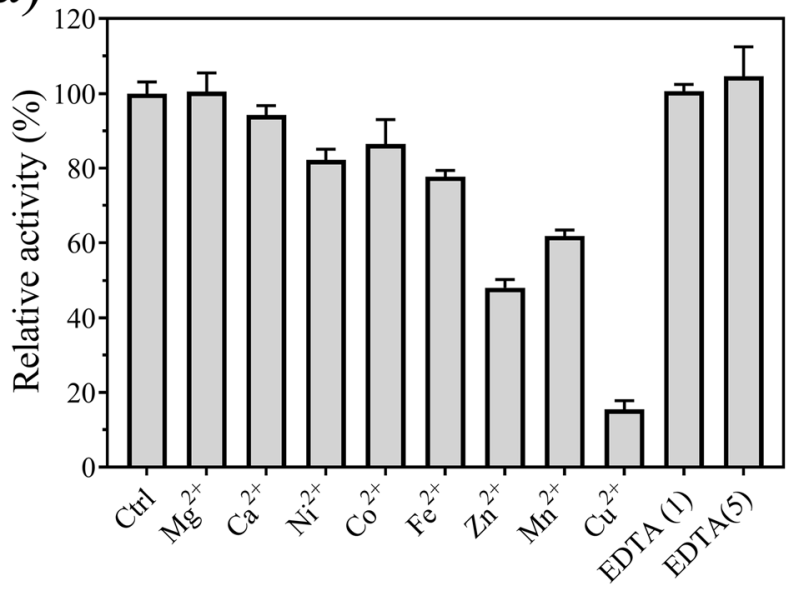

(b)

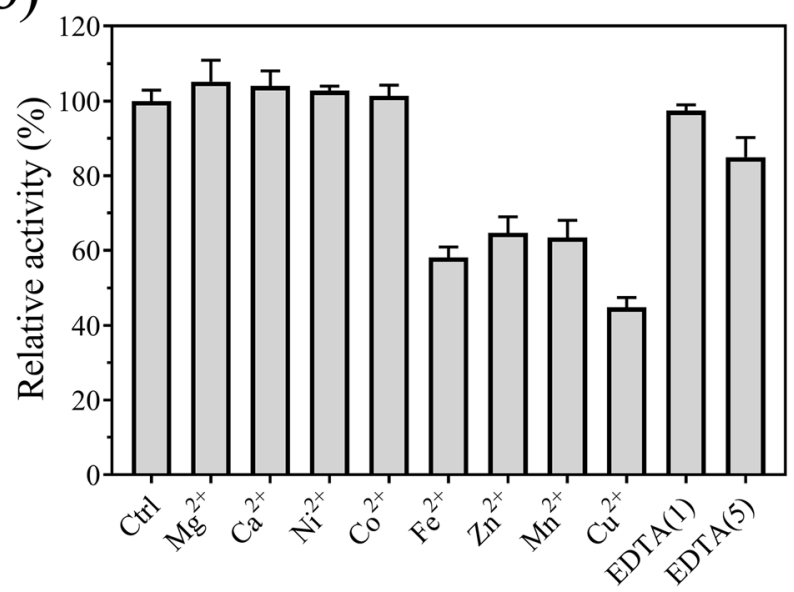

Fig. 4 Effect of metal ions on the activities of recombinant enzymes TtABF51A (a) or EpABF62C (b). Each metal ion or EDTA was added into the reaction buffer at final concentration of 1 or $5 \mathrm{mM}$ (only EDTA). Enzymatic activities on WAX were assayed under standard conditions. Ctrl, untreated enzyme. Relative activity was calculated using the activity of the untreated enzyme as $100 \%$. Error bars represent SDs from three independent assays

Meanwhile, the amount of released arabinose from WAX by the combined enzymes was 2.11 times that of TtABF51A alone. Compared with the individual enzymes, the combined enzymes EpXYN1 and EpABF62C released 3.38 times of xylose or 1.65 times of xylobiose from the substrate, respectively. The amount of released arabinose did not change by this enzyme combination. When the both ABFs were combined with EpXYN1, the amounts of liberated xylose and xylobiose were up to 4.81 times and 2.57 times of those by single xylanase, respectively. The degrees of synergy were $2.07,1.16$, and 1.98 for the combinations of EpXYN1 with TtABF $51 \mathrm{~A}$, or EpABF62C, or the two ABFs, respectively. These results from HPLC analysis were in agreement with reducing-end analysis by the Somogyi-Nelson method (Supplementary Fig. S8). (a)

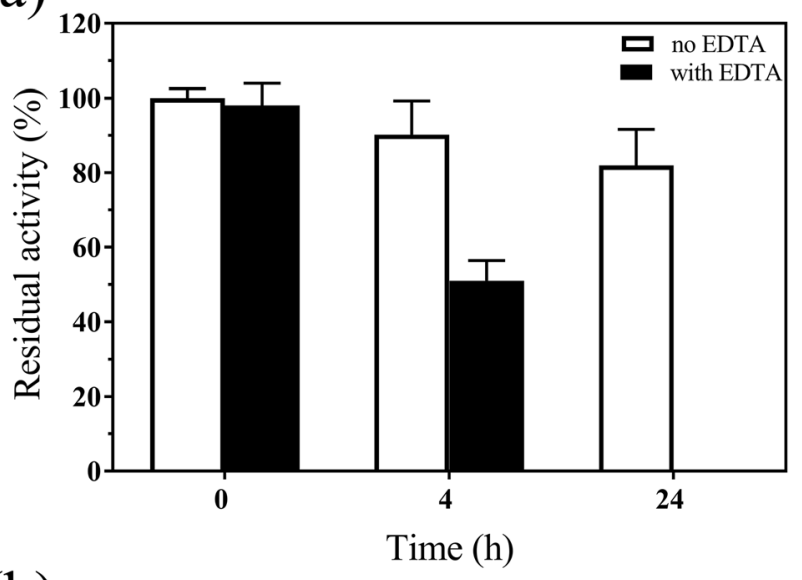

(b)

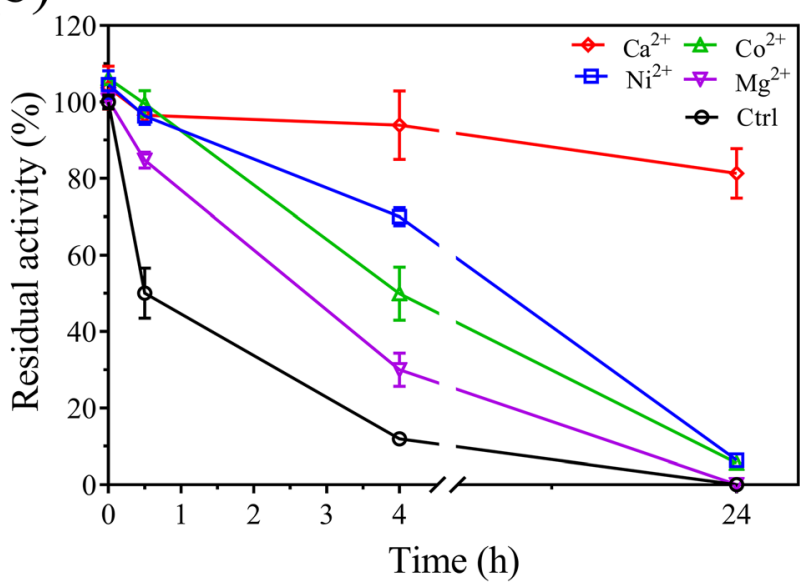

Fig. 5 Effect of metal ions on the thermal stability of recombinant enzyme EpABF62C. a Analysis of thermal stability of enzyme EpABF62C with or without EDTA. Pure protein EpABF62C $(0.1 \mu \mathrm{g} /$ $\mu \mathrm{L}, 100 \mu \mathrm{L}$ ) was mixed with EDTA (final concentration $1 \mathrm{mM}$ ) at $4{ }^{\circ} \mathrm{C}$ for $1 \mathrm{~h}$. The residual activity of the enzyme was assayed after incubation at $55{ }^{\circ} \mathrm{C}$ for 4 or $24 \mathrm{~h}$, respectively. b Comparison of the thermal stabilities of enzyme EpABF62C in the presence of different metal ions. Enzyme EpABF62C without metal ions was prepared by the EDTA treatment as described in the "Materials and methods" section and mixed with different metal ions (final concentration $1 \mathrm{mM}$ ) at $4{ }^{\circ} \mathrm{C}$ for $1 \mathrm{~h}$. After treatment at $60^{\circ} \mathrm{C}$ for 0.5 to $24 \mathrm{~h}$, the residual activity of the enzyme was determined under standard conditions using WAX as substrate. Ctrl, no metal ions. Relative activity was calculated using the initial activity of the untreated enzyme as $100 \%$. Error bars represent SDs from three independent assays

\section{Discussion}

The thermophilic fungus T. terrestris and the mesophilic fungus $E$. parvum are important sources for production of thermotolerant enzymes (Garcia-Huante et al. 2017; Long et al. 2016; Tang et al. 2019). In the present study, two ABF (TtABF51A and EpABF62C) encoding genes were obtained from the two fungi by artificially synthesis or RT-PCR method. On the basis of sequence analysis, proteins TtABF51A (640 aa) and EpABF62C (328 aa) were classified as GH51 and GH62 families, respectively. A predicted CBM domain 
(a)

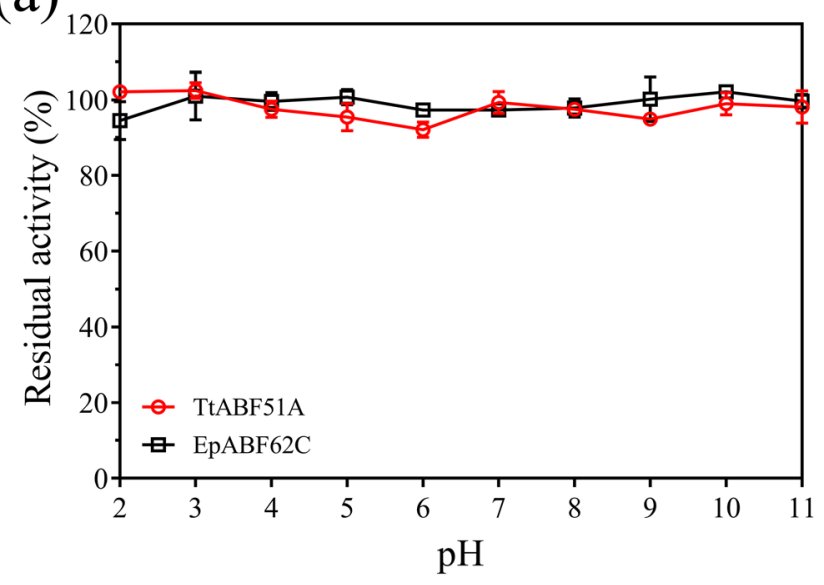

(b)

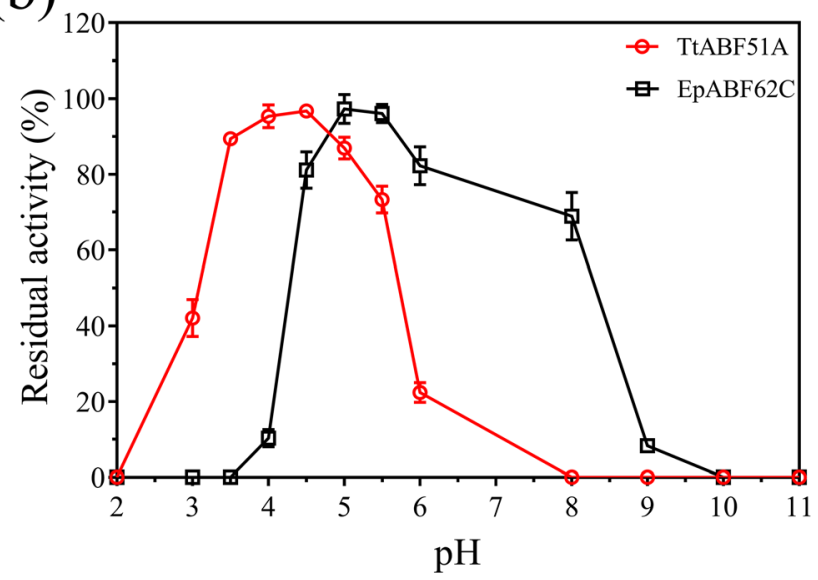

Fig. 6 Effect of $\mathrm{pH}$ on the stabilities of recombinant enzymes under low (a) or high (b) temperatures. Pure enzymes $(0.1 \mu \mathrm{g} / \mu \mathrm{L})$ were added in glycine- $\mathrm{HCl}$ buffer $(\mathrm{pH} 2.0-3.0)$, sodium acetate buffer $(\mathrm{pH} 4.0-6.0$ ), sodium phosphate buffer $(\mathrm{pH} 7.0)$, or glycine- $\mathrm{NaOH}$ buffer $(\mathrm{pH} 8.0$ 11.0), respectively. After incubated at $4{ }^{\circ} \mathrm{C}$ (a) or $55^{\circ} \mathrm{C}$ (b) for $24 \mathrm{~h}$, residual activities of the enzymes were assayed under standard conditions using WAX as substrate. Because the proteins precipitated in the buffer after treatment at $55^{\circ} \mathrm{C}$, the data of $\mathrm{pH} 7.0$ in Fig. $7 \mathrm{~b}$ were removed. Relative activity was calculated using the activity of the untreated enzyme as $100 \%$. Error bars represent SDs from three independent assays

(147 aa) belonging to CBM_4_9 superfamily exists at the Nterminal of TtABF51A. There is only limited documentation of the CBM of the GH51 family ABFs. Sin et al. (2016) reported that the GH51 ABF FaARA1 from Fragaria $\times$ ananassa contains a CBM corresponding to the superfamily CBM_4_9, and the recombinant CBM protein showed a strong affinity to homogalacturonans and a low affinity to microcrystalline cellulose. Due to the various roles of CBMs in polysaccharide degrading enzymes (Gilbert et al. 2013; Guillen et al. 2010), further research is needed to clarify the CBM function of TtABF51A. Proteins TtABF51A and EpABF62C have medium (53\%) or high $(73 \%)$ sequence identities with other characterized ABFs, respectively. The two proteins contain conserved residues, e.g., for the active sites and/or the "SHG" motif of ABFs belonging to GH51 or (a)

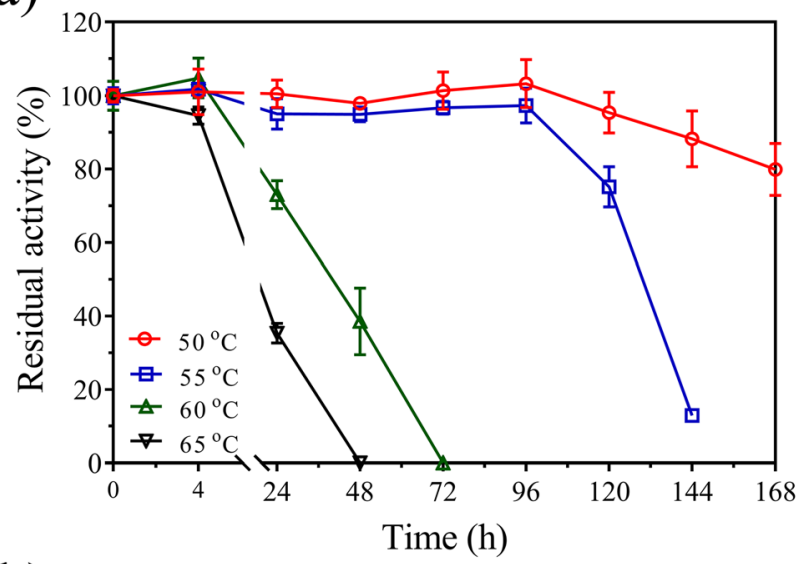

(b)

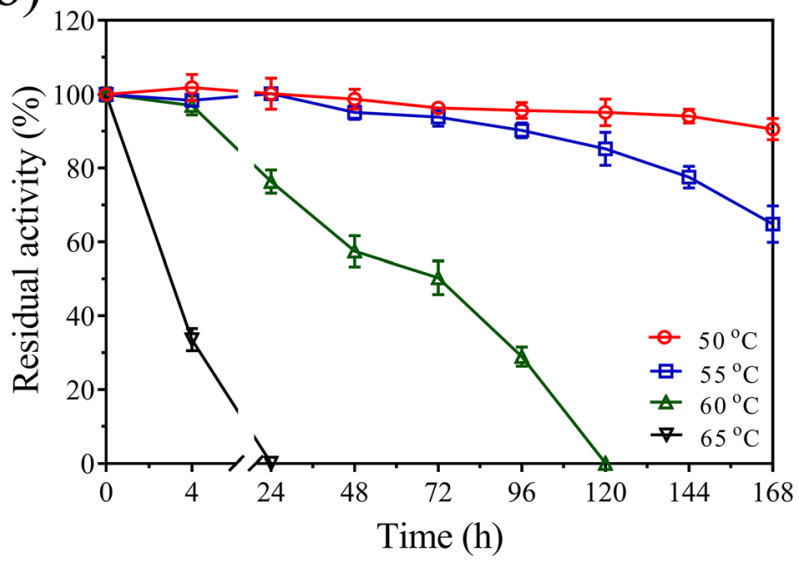

Fig. 7 Thermal stabilities of recombinant enzymes TtABF51A (a) and EpABF62C (b). Pure enzymes (final concentration $0.1 \mu \mathrm{g} / \mu \mathrm{L}$ ) were added in $50 \mathrm{mM}$ of sodium acetate buffer with $\mathrm{pH} 4.5$ (for TtABF51A) or 5.0 (for EpABF62C), and incubated at 50,55 , or $60^{\circ} \mathrm{C}$ for up to $168 \mathrm{~h}$. Enzyme EpABF62C was treated with $5 \mathrm{mM}$ of $\mathrm{CaCl}_{2}$ before the thermal stability test. After 4-fold dilution, residual activities of the enzymes on WAX were assayed under standard conditions. Relative activity was calculated using the activity of the untreated enzyme as $100 \%$. Error bars represent SDs from three independent assays

GH62 families. The predicted structure of the catalytic region of TtABF51A was organized into a $(\beta / \alpha)_{8}$-barrel domain and a $\beta$-sandwich domain, which is consistent with the crystal structures of other GH51 ABFs from G. stearothermophilus T-6 or Clostridium thermocellum (Hovel et al. 2003; Taylor et al. 2006). Meanwhile, the typical 5-fold $\beta$-propeller structure and the conserved catalytic triad of ABFs of the GH62 family (Contesini et al. 2017; Maehara et al. 2014; Wang et al. 2014) were predicted in the protein model structure of EpABF62C.

TtABF51A and EpABF62C displayed the highest catalytic activities at high temperature $\left(65^{\circ} \mathrm{C}\right)$ and acidic $\mathrm{pH}(4.0-5.0)$ toward natural substrates. TtABF51A showed considerable activity against different substrates including pNPAraf, arabinoxylans (from wheat or rye), and arabinan (from sugarbeet). Like most of ABFs from GH62 family (Sarch et al. 2019; Wang et al. 2014; Wilkens et al. 2017), 
Table 1 Specific activity and kinetic constants of recombinant enzymes toward various substrates

\begin{tabular}{llllll}
\hline Enzyme & Substrate & $\begin{array}{l}\text { Specific activity } \\
(\mathrm{U} / \mathrm{mg})\end{array}$ & $\begin{array}{l}K_{\mathrm{m}}(\mathrm{mM} \text { or } \mathrm{mg} / \\
\mathrm{mL})^{\mathrm{d}}\end{array}$ & $\begin{array}{l}V_{\max }(\mu \mathrm{mol} / \mathrm{min} / \\
\mathrm{mg})\end{array}$ & $k_{\text {cat }}\left(\mathrm{s}^{-1}\right)$ \\
\hline TtABF51A & pNPAraf & $83.39 \pm 3.10$ & $0.30 \pm 0.02$ & $107.80 \pm 2.54$ & $123.31 \pm 2.91$ \\
& WAX & $39.66 \pm 0.93$ & $4.63 \pm 0.22$ & $63.24 \pm 1.35$ & $72.34 \pm 1.54$ \\
& RAX & $32.24 \pm 0.28$ & $1.77 \pm 0.12$ & $39.17 \pm 0.70$ & $44.81 \pm 0.80$ \\
& SBA & $25.69 \pm 1.16$ & $5.52 \pm 0.40$ & $36.61 \pm 1.03$ & $41.88 \pm 1.18$ \\
EpABF62C & pNPAraf & $0.26 \pm 0.02^{\mathrm{c}}$ & - & - & - \\
& WAX & $42.58 \pm 2.28$ & $4.98 \pm 0.53$ & $69.93 \pm 2.89$ & $39.46 \pm 1.63$ \\
& WAX $^{\mathrm{b}}$ & $45.46 \pm 2.44$ & $6.08 \pm 0.70$ & $74.50 \pm 3.64$ & $42.04 \pm 2.05$ \\
& RAX $^{\mathrm{b}}$ & $94.10 \pm 3.11$ & $7.73 \pm 0.85$ & $178.70 \pm 8.75$ & $100.84 \pm 4.94$ \\
& SBA $^{\mathrm{b}}$ & $1.93 \pm 0.08^{\mathrm{c}}$ & - & - & - \\
\hline
\end{tabular}

Except as indicated, all of the enzymatic activities were assayed under standard conditions. The specific activities toward natural substrates were assayed using $8 \mathrm{mg} / \mathrm{mL}$ of substrate. The $k_{\mathrm{cat}}$ values of TtABF51A and EpABF62C were calculated based on the theoretical MW values 68.63 and $33.86 \mathrm{kDa}$, respectively. ${ }^{\mathrm{a}} \mathrm{Ca}^{2+}$ was removed from the enzyme; ${ }^{b}$ the enzyme was treated with $\mathrm{CaCl}_{2}(2 \mathrm{mM}){ }^{\mathrm{c}}$ the reaction time was $1 \mathrm{~h} ;{ }^{\mathrm{d}}$ the unit of $K_{\mathrm{m}}$ for pNPAraf is $\mathrm{mM}$

pNPAraf, 4-nitrophenyl- $\alpha$-L-arabinofuranoside; WAX, wheat arabinoxylan (low viscosity); RAX, rye arabinoxylan; SBA, sugarbeet arabinan. ND, not detectable; -, no analysis
EpABF62C showed specificity for the release of arabinose from arabinoxylans. Like some ABFs of the GH43 family
(Ahmed et al. 2013; Valls et al. 2016), EpABF62C displayed about two times greater specific activities toward RAX than
Fig. $8{ }^{1} \mathrm{H}$ NMR analysis of enzymatic products of wheat arabinoxylan. a Treatment of lowviscosity wheat arabinoxylan (WAX) with (red line) or without (gray line) enzyme TtABF51A. b Treatment of WAX with (blue line) or without (gray line) enzyme EpABF62C. The peaks with chemical shifts at 5.41, 5.28, and 5.23 ppm represent the monosubstituted $\alpha-1,3-\mathrm{L}-\mathrm{Ara} f$, disubstituted $\alpha-1,3-\mathrm{L}-\mathrm{Ara} f$, and disubstituted $\alpha-1,2-\mathrm{L}-\mathrm{Ara} f$ in the substrate, respectively

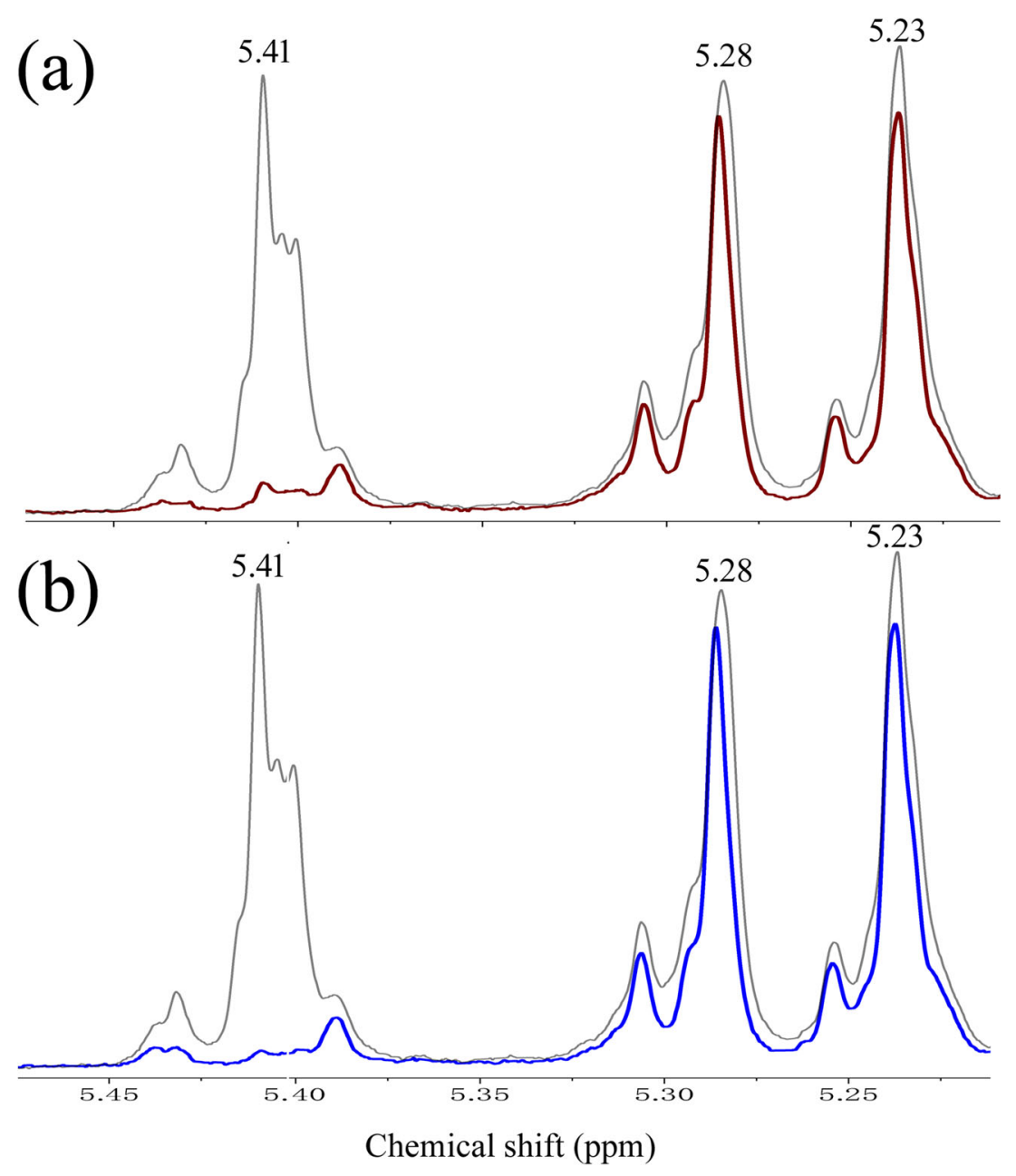


Table 2 Hydrolytic products of wheat arabinoxylan by different enzyme combinations

\begin{tabular}{llllll}
\hline Enzyme combination & Xylose $(\mathrm{mg} / \mathrm{g})$ & Xylobiose $(\mathrm{mg} / \mathrm{g})$ & Xylotriose $(\mathrm{mg} / \mathrm{g})$ & Arabinose $(\mathrm{mg} / \mathrm{g})$ & Degree of synergy \\
\hline EpXYN1 & $24.26 \pm 0.55$ & $92.54 \pm 2.01$ & $73.69 \pm 1.76$ & ND & - \\
TtABF51A & $\mathrm{ND}$ & $\mathrm{ND}$ & $\mathrm{ND}$ & $87.54 \pm 2.56$ & - \\
EpABF62C & $\mathrm{ND}$ & $\mathrm{ND}$ & $\mathrm{ND}$ & $81.74 \pm 0.99$ & - \\
TtABF51A + EpABF62C & $\mathrm{ND}$ & $\mathrm{ND}$ & $\mathrm{ND}$ & $87.21 \pm 4.72$ & - \\
EpXYN1 + TtABF51A & $60.39 \pm 3.45$ & $313.00 \pm 18.48$ & $17.63 \pm 3.16$ & $185.07 \pm 8.66$ & 2.07 \\
EpXYN1 + EpABF62C & $81.91 \pm 3.36$ & $152.29 \pm 6.86$ & $\mathrm{ND}$ & $82.92 \pm 4.31$ & 1.16 \\
EpXYN1 + TtABF51A + EpABF62C & $116.60 \pm 6.63$ & $238.14 \pm 2.79$ & $\mathrm{ND}$ & $196.00 \pm 3.36$ & 1.98 \\
\hline
\end{tabular}

In $200 \mu \mathrm{L}$ of sodium acetate buffer ( $50 \mathrm{mM}, \mathrm{pH} 4.5), 0.5 \mathrm{mg}$ of wheat arabinoxylan (low viscosity) was mixed with xylanase (EpXYN1) and/or arabinofuranosidases (TtABF51A or EpABF62C). The dosage of each enzyme was $0.5 \mu \mathrm{g}$ per reaction, and the same mass of bovine serum albumin was used as a control. The amount of monosaccharides and oligosaccharides were quantified by HPLC analysis

ND, not detectable; -, no data

those on WAX. A reasonable explanation was that the difference of arabinose-substituted xylose residues distributed in the two substrates (Ahmed et al. 2013; Valls et al. 2016). In this work, it was confirmed by NMR that the substrate RAX contains approximately two times greater $\alpha$-1,3-L-Ara $f$ monosubstituted xylose than WAX, as described in the previous research (Pitkanen et al. 2009). Furthermore, EpABF62C showed specificity in removing mono-substituted $\alpha-1,3-\mathrm{L}-$ Araf residues from WAX by ${ }^{1} \mathrm{HNMR}$ analysis. The regioselectivity of EpABF62C toward the substrate and the different content of mono-substituted $\alpha$-1,3-L-Ara $f$ between the two substrates resulted in the enzyme having a higher specific activity against RAX than against WAX. TtABF51A showed the same regioselectivity toward the arabinoxylan and only displayed a higher activity on RAX than that on WAX at a low substrate concentration (below $4 \mathrm{mg} / \mathrm{mL}$ ). It was speculated that the activity of the enzyme was affected by the high viscosity of the substrate under the assay conditions.

The catalytic activities of ABFs have been shown to be affected by some divalent metal ions (Hu et al. 2018; Kaur et al. 2015; Komeno et al. 2019). In our study, the activity of TtABF51A was suppressed by $\mathrm{Cu}^{2+}, \mathrm{Zn}^{2+}, \mathrm{Mn}^{2+}, \mathrm{Fe}^{2+}, \mathrm{Ni}^{2+}$, $\mathrm{Co}^{2+}$, and $\mathrm{Ca}^{2+}$ at different levels. Meanwhile, cations $\mathrm{Cu}^{2+}$, $\mathrm{Fe}^{2+}, \mathrm{Zn}^{2+}$, and $\mathrm{Mn}^{2+}$ negatively affected the activity of EpABF62C. In literature, a calcium ion is normally observed in the central channel of 5-fold $\beta$-propeller structures of ABFs belonging to GH62 or GH43 families (Contesini et al. 2017; Kaur et al. 2015; Santos et al. 2014; Wang et al. 2014). Several ABFs of the GH43 family are reported to need $\mathrm{Ca}^{2+}$ for enzymatic activity (Ahmed et al. 2013; de Camargo et al. 2018). The specific activity of EpABF62C had a slight change in the presence of calcium, which is consistent to the result that $\mathrm{Ca}^{2+}$ did not significantly affect the catalytic activities of ABFs of the GH62 family (Kaur et al. 2015; Siguier et al. 2014; Wang et al. 2014). The addition of EDTA ( $5 \mathrm{mM}$ ) led to a decrease of the activity of EpABF62C under the tested conditions. Furthermore, our data indicated that calcium was a critical factor for the thermal stability of the enzyme. The conservative "SHG" motif of GH62 family (Wilkens et al. 2017) involved in $\mathrm{Ca}^{2+}$ coordination exists in the protein sequence of EpABF62C. Ahmed et al. (2013) found that $\mathrm{Ca}^{2+}$ ion imparted the thermal stability of enzyme Ct43Araf from $C$. thermocellum using protein melting-curve analysis. Calcium-dependent thermal stability was reported in diverse proteins including xylanase and glucosidase (Kobayashi et al. 2011; Shi et al. 2013). Part of the explanation was that calcium binding led to structural stability of CMB domain or $(\beta / \alpha)_{8^{-}}$ barrel in these proteins (Ahmed et al. 2013; de Sanctis et al. 2010; Kobayashi et al. 2011; Shi et al. 2013).

The two enzymes exhibited high stabilities in a wide $\mathrm{pH}$ region $(2.0-11.0)$ at a low temperature $\left(4{ }^{\circ} \mathrm{C}\right)$ but not at a high temperature $\left(55^{\circ} \mathrm{C}\right)$. The thermal stabilities of the enzymes at $55^{\circ} \mathrm{C}$ were tightly related to the $\mathrm{pH}$ value of buffer. Enzyme TtABF51A showed the highest thermal stability at $\mathrm{pH} 4.0$ 4.5 , which overlaps the optimal $\mathrm{pH}$ for catalytic ability. For EpABF62C, pH 5.0 was the best for the thermal stability and high (85-90\%) catalytic activity. Under such reaction $\mathrm{pH}$ conditions, long hydrolysis times or recyclable utilization of enzymes may be considered. Under the optimal conditions, enzymes TtABF51A and EpABF62C were stable after incubation at $55^{\circ} \mathrm{C}$ for 4 or 6 days, respectively. The two enzymes displayed higher thermal stabilities than many reported ABFs (Hu et al. 2018; Maehara et al. 2014; Sarch et al. 2019; Tu et al. 2019; Wang et al. 2014; Zheng et al. 2018).

Previous studies have indicated that debranching is a key step in the conversion of hemicellulose into monosaccharides or shorter oligosaccharides (Gao et al. 2011; Moreira and Filho 2016; Zheng et al. 2018). Endo-xylanase EpXYN1 (GH10 family) is a thermotolerant enzyme from E. parvum and can hydrolyze different xylans into xylobiose, xylotriose, and xylose (Long et al. 2018b). Compared with individual enzymes, the amounts of released xylose or xylobiose from WAX were increased 0.6-3.8 times by EpXYN1 in combination with TtABF51A and/or EpABF62C. Obviously, the 
removal of Araf residues on the xylose residues enhanced the hydrolytic action of EpXYN1. Similar to what has been previously reported (Hu et al. 2018; Yang et al. 2015), the hydrolysis action of EpXYN1 together with TtABF51A increased the release of arabinose from WAX by 1.11 times. The same phenomenon did not appear in the synergistic degradation of EpXYN1 and EpABF62C. Combined with the same regioselectivities of the two enzymes toward the arabinose polysaccharides WAX, a possible speculation is that TtABF51A can remove the $\alpha-1,3$-L-Araf or $\alpha-1,2$-L-Araf from di-substituted xylose residues in arabinose oligosaccharides. In addition, the highest level of xylose but not xylobiose (or xylotriose) was released from WAX by EpXYN1 in combination with the two ABFs. More studies need to be done to understand the detailed mode of action of the two enzymes toward different substrates and explain the mechanism of synergistic degradation.

Authors' contributions L.L. performed the characterization of the enzymes, ${ }^{1} \mathrm{H}$ NMR analysis, synergistic degradation experiment, and prepared the manuscript; L.S. performed the molecular experiments and enzyme expressions, and helped with the ${ }^{1} \mathrm{H}$ NMR analysis; Q.L. performed the construction of recombinant $T$. reesei; S.D. helped with the data analysis and designed the research; F.J.S.J. performed the HPLC experiments, and advised and hosted L.L. as a visiting scientist at the USDA Forest Service, Forest Products Laboratory. All authors read and approved the final manuscript.

Funding This work was supported by grants from the Jiangsu Provincial Government Scholarship for Overseas Studies, from the National Natural Science Foundation of China (research project no. 30370043), the Science and Technology Project of Guizhou Province in China (grant no. [2019]2333), and the Priority Academic Program Development of Jiangsu Higher Education Institutions. Additional support was also provided by the Institute for Microbial and Biochemical Technology, Forest Products Laboratory, USDA Forest Service where L.L. performed the studies reported in this publication.

\section{Compliance with ethical standards}

Conflict of interest The authors declare that they have no conflict of interest.

Ethical approval This article does not contain any studies with human participants or animals performed by any of the authors.

Open Access This article is licensed under a Creative Commons Attribution 4.0 International License, which permits use, sharing, adaptation, distribution and reproduction in any medium or format, as long as you give appropriate credit to the original author(s) and the source, provide a link to the Creative Commons licence, and indicate if changes were made. The images or other third party material in this article are included in the article's Creative Commons licence, unless indicated otherwise in a credit line to the material. If material is not included in the article's Creative Commons licence and your intended use is not permitted by statutory regulation or exceeds the permitted use, you will need to obtain permission directly from the copyright holder. To view a copy of this licence, visit http://creativecommons.org/licenses/by/4.0/.

\section{References}

Ahmed S, Luis AS, Bras JLA, Ghosh A, Gautam S, Gupta MN, Fontes CMGA, Goyal A (2013) A novel $\alpha$-L-arabinofuranosidase of family 43 glycoside hydrolase (Ct43Araf) from Clostridium thermocellum. PLoS One 8(9):e73575. https://doi.org/10.1371/ journal.pone. 0073575

Amore A, Amoresano A, Birolo L, Henrissat B, Leo G, Palmese A, Faraco V (2012) A family GH51 $\alpha$-L-arabinofuranosidase from Pleurotus ostreatus: identification, recombinant expression and characterization. Appl Microbiol Biotechnol 94(4):995-1006. https://doi.org/10.1007/s00253-011-3678-4

Berka RM, Grigoriev IV, Otillar R, Salamov A, Grimwood J, Reid I, Ishmael N, John T, Darmond C, Moisan MC, Henrissat B, Coutinho PM, Lombard V, Natvig DO, Lindquist E, Schmutz J, Lucas S, Harris P, Powlowski J, Bellemare A, Taylor D, Butler G, de Vries RP, Allijn IE, van den Brink J, Ushinsky S, Storms R, Powell AJ, Paulsen IT, Elbourne LD, Baker SE, Magnuson J, Laboissiere S, Clutterbuck AJ, Martinez D, Wogulis M, de Leon AL, Rey MW, Tsang A (2011) Comparative genomic analysis of the thermophilic biomass-degrading fungi Myceliophthora thermophila and Thielavia terrestris. Nat Biotechnol 29(10):922-927. https:// doi.org/10.1038/nbt.1976

Bounias M (1980) N-(1-Naphthyl) ethylenediamine dihydrochloride as a new reagent for nanomole quantification of sugars on thin-layer plates by a mathematical calibration process. Anal Biochem 106(2):291-295. https://doi.org/10.1016/0003-2697(80)90523-0

Bouraoui H, Desrousseaux ML, Ioannou E, Alvira P, Manai M, Remond C, Dumon C, Fernandez-Fuentes N, O'Donohue MJ (2016) The GH51 $\alpha$-L-arabinofuranosidase from Paenibacillus sp. THS1 is multifunctional, hydrolyzing main-chain and side-chain glycosidic bonds in heteroxylans. Biotechnol Biofuels 9:140. https://doi.org/ 10.1186/s13068-016-0550-x

Brunecky R, Chung D, Sarai NS, Hengge N, Russell JF, Young J, Mittal A, Pason P, Vander Wall T, Michener W, Shollenberger T, Westpheling J, Himmel ME, Bomble YJ (2018) High activity CAZyme cassette for improving biomass degradation in thermophiles. Biotechnol Biofuels 11:22. https://doi.org/10.1186/s13068018-1014-2

Chadha BS, Kaur B, Basotra N, Tsang A, Pandey A (2019) Thermostable xylanases from thermophilic fungi and bacteria: current perspective. Bioresour Technol 277:195-203. https://doi.org/10.1016/j.biortech. 2019.01.044

Contesini FJ, Liberato MV, Rubio MV, Calzado F, Zubieta MP, RianoPachon DM, Squina FM, Bracht F, Skaf MS, Damasio AR (2017) Structural and functional characterization of a highly secreted $\alpha$-Larabinofuranosidase (GH62) from Aspergillus nidulans grown on sugarcane bagasse. Biochim Biophys Acta, Proteins Proteomics 1865(12):1758-1769. https://doi.org/10.1016/j.bbapap.2017.09. 001

de Camargo BR, Claassens NJ, Quirino BF, Noronha EF, Kengen SWM (2018) Heterologous expression and characterization of a putative glycoside hydrolase family 43 arabinofuranosidase from Clostridium thermocellum B8. Enzym Microb Technol 109:74-83. https://doi.org/10.1016/j.enzmictec.2017.09.014

de Cassia PJ, Paganini Marques N, Rodrigues A, Brito de Oliveira T, Boscolo M, da Silva R, Gomes E, Bocchini Martins DA (2015) Thermophilic fungi as new sources for production of cellulases and xylanases with potential use in sugarcane bagasse saccharification. J Appl Microbiol 118(4):928-939. https://doi.org/10.1111/ jam. 12757

de Sanctis D, Inacio JM, Lindley PF, de Sa-Nogueira I, Bento I (2010) New evidence for the role of calcium in the glycosidase reaction of GH43 arabinanases. FEBS J 277(21):4562-4574. https://doi.org/10. $1111 / \mathrm{j} .1742-4658.2010 .07870 . x$ 
Debeche T, Cummings N, Connerton I, Dereire P, O’Donohue MJ (2000) Genetic and biochemical characterization of a highly thermostable $\alpha$-L-arabinofuranosidase from Thermobacillus xylanilyticus. Appl Environ Microbiol 66(4):1734-1736. https://doi.org/10.1128/ AEM.66.4.1734-1736.2000

dos Santos CR, Squina FM, Navarro AM, Oldiges DP, Paes Leme AF, Ruller R, Mort AJ, Prade R, Murakami MT (2011) Functional and biophysical characterization of a hyperthermostable GH51 $\alpha$-Larabinofuranosidase from Thermotoga petrophila. Biotechnol Lett 33(1):131-137. https://doi.org/10.1007/s10529-010-0409-3

dos Santos CR, de Giuseppe PO, de Souza FHM, Zanphorlin LM, Domingues MN, Pirolla RAS, Honorato RV, Tonoli CCC, de Morais MAB, de Matos Martins VP, Fonseca LM, Buchli F, de Oliveira PSL, Gozzo FC, Murakami MT (2018) The mechanism by which a distinguishing arabinofuranosidase can cope with internal di-substitutions in arabinoxylans. Biotechnol Biofuels 11:223. https://doi.org/10.1186/s13068-018-1212-y

Gao D, Uppugundla N, Chundawat SP, Yu X, Hermanson S, Gowda K, Brumm P, Mead D, Balan V, Dale BE (2011) Hemicellulases and auxiliary enzymes for improved conversion of lignocellulosic biomass to monosaccharides. Biotechnol Biofuels 4:5. https://doi.org/ 10.1186/1754-6834-4-5

Garcia-Huante Y, Cayetano-Cruz M, Santiago-Hernandez A, CanoRamirez C, Marsch-Moreno R, Campos JE, Aguilar-Osorio G, Benitez-Cardoza CG, Trejo-Estrada S, Hidalgo-Lara ME (2017) The thermophilic biomass-degrading fungus Thielavia terrestris Co3Bag1 produces a hyperthermophilic and thermostable $\beta-1,4-$ xylanase with exo- and endo-activity. Extremophiles 21(1):175186. https://doi.org/10.1007/s00792-016-0893-z

Gilbert HJ, Knox JP, Boraston AB (2013) Advances in understanding the molecular basis of plant cell wall polysaccharide recognition by carbohydrate-binding modules. Curr Opin Struct Biol 23(5):669677. https://doi.org/10.1016/j.sbi.2013.05.005

Goncalves TA, Damasio AR, Segato F, Alvarez TM, Bragatto J, Brenelli LB, Citadini AP, Murakami MT, Ruller R, Paes Leme AF, Prade RA, Squina FM (2012) Functional characterization and synergic action of fungal xylanase and arabinofuranosidase for production of xylooligosaccharides. Bioresour Technol 119:293-299. https:// doi.org/10.1016/j.biortech.2012.05.062

Guillen D, Sanchez S, Rodriguez-Sanoja R (2010) Carbohydrate-binding domains: multiplicity of biological roles. Appl Microbiol Biotechnol 85(5):1241-1249. https://doi.org/10.1007/s00253-0092331-y

Hovel K, Shallom D, Niefind K, Belakhov V, Shoham G, Baasov T, Shoham Y, Schomburg D (2003) Crystal structure and snapshots along the reaction pathway of a family $51 \alpha$-L-arabinofuranosidase. EMBO J 22(19):4922-4932. https://doi.org/10.1093/emboj/cdg494

Hu Y, Zhao Y, Tian S, Zhang G, Li Y, Li Q, Gao J (2018) Screening of a novel glycoside hydrolase family $51 \alpha$-L-arabinofuranosidase from Paenibacillus polymyxa KF-1: cloning, expression, and characterization. Catalysts 8(12):589. https://doi.org/10.3390/catal8120589

Jia L, Budinova GALG, Takasugi Y, Noda S, Tanaka T, Ichinose H, Goto M, Kamiya N (2016) Synergistic degradation of arabinoxylan by free and immobilized xylanases and arabinofuranosidase. Biochem Eng J 114:268-275. https://doi.org/10.1016/j.bej.2016.07.013

Kaur AP, Nocek BP, Xu X, Lowden MJ, Leyva JF, Stogios PJ, Cui H, Di Leo R, Powlowski J, Tsang A, Savchenko A (2015) Functional and structural diversity in GH62 $\alpha$-L-arabinofuranosidases from the thermophilic fungus Scytalidium thermophilum. Microb Biotechnol 8(3):419-433. https://doi.org/10.1111/1751-7915. 12168

Kobayashi M, Hondoh H, Mori H, Saburi W, Okuyama M, Kimura A (2011) Calcium ion-dependent increase in thermostability of dextran glucosidase from Streptococcus mutans. Biosci Biotechnol Biochem 75(8):1557-1563. https://doi.org/10.1271/bbb.110256
Komeno M, Hayamizu H, Fujita K, Ashida H (2019) Two novel $\alpha$-Larabinofuranosidases from Bifidobacterium longum subsp. longum belonging to glycoside hydrolase family 43 cooperatively degrade arabinan. Appl Environ Microbiol 85(6). https://doi.org/10.1128/ AEM.02582-18

Kumar S, Stecher G, Li M, Knyaz C, Tamura K (2018) MEGA X: molecular evolutionary genetics analysis across computing platforms. Mol Biol Evol 35(6):1547-1549. https://doi.org/10.1093/ molbev/msy096

Larkin MA, Blackshields G, Brown NP, Chenna R, McGettigan PA, McWilliam H, Valentin F, Wallace IM, Wilm A, Lopez R, Thompson JD, Gibson TJ, Higgins DG (2007) Clustal W and Clustal X version 2.0. Bioinformatics 23(21):2947-2948. https:// doi.org/10.1093/bioinformatics/btm404

Lee SH, Lee YE (2014) Cloning, expression, and characterization of a thermostable GH51 $\alpha$-L-arabinofuranosidase from Paenibacillus sp. DG-22. J Microbiol Biotechnol 24(2):236-244. https://doi.org/ 10.4014/jmb.1308.08078

Liu J, Chinga-Carrasco G, Cheng F, Xu W, Willför S, Syverud K, Xu C (2016) Hemicellulose-reinforced nanocellulose hydrogels for wound healing application. Cellulose 23(5):3129-3143. https://doi. org/10.1007/s10570-016-1038-3

Lombard V, Ramulu HG, Drula E, Coutinho PM, Henrissat B (2014) The carbohydrate-active enzymes database (CAZy) in 2013. Nucleic Acids Res 42(D1):D490-D495. https://doi.org/10.1093/nar/ gkt1178

Long L, Ding D, Han Z, Zhao H, Lin Q, Ding S (2016) Thermotolerant hemicellulolytic and cellulolytic enzymes from Eupenicillium parvum 4-14 display high efficiency upon release of ferulic acid from wheat bran. J Appl Microbiol 121(2):422-434. https://doi. org/10.1111/jam.13177

Long L, Lin Q, Shi Y, Wang J, Ding S (2018a) Highly efficient transformation of a (hemi-)cellulases-producing fungus Eupenicillium parvum 4-14 by Agrobacterium tumefaciens. J Microbiol Methods 146:40-45. https://doi.org/10.1016/j.mimet.2018.01.013

Long L, Xu M, Shi Y, Lin Q, Wang J, Ding S (2018b) Characterization of two new endo- $\beta$-1,4-xylanases from Eupenicillium parvum 4-14 and their applications for production of feruloylated oligosaccharides. Appl Biochem Biotechnol 186(4):816-833. https://doi.org/ 10.1007/s12010-018-2775-6

Long L, Zhao H, Ding D, Xu M, Ding S (2018c) Heterologous expression of two Aspergillus niger feruloyl esterases in Trichoderma reesei for the production of ferulic acid from wheat bran. Bioprocess Biosyst Eng 41(5):593-601. https://doi.org/10.1007/ s00449-018-1894-3

Maehara T, Fujimoto Z, Ichinose H, Michikawa M, Harazono K, Kaneko S (2014) Crystal structure and characterization of the glycoside hydrolase family $62 \alpha$-L-arabinofuranosidase from Streptomyces coelicolor. J Biol Chem 289(11):7962-7972. https://doi.org/10. 1074/jbc.M113.540542

McCleary BV, McKie VA, Draga A, Rooney E, Mangan D, Larkin J (2015) Hydrolysis of wheat flour arabinoxylan, acid-debranched wheat flour arabinoxylan and arabino-xylo-oligosaccharides by $\beta$ xylanase, $\alpha$-L-arabinofuranosidase and $\beta$-xylosidase. Carbohydr Res 407:79-96. https://doi.org/10.1016/j.carres.2015.01.017

Mewis K, Lenfant N, Lombard V, Henrissat B (2016) Dividing the large glycoside hydrolase family 43 into subfamilies: a motivation for detailed enzyme characterization. Appl Environ Microbiol 82(6): 1686-1692. https://doi.org/10.1128/AEM.03453-15

Moreira LR, Filho EX (2016) Insights into the mechanism of enzymatic hydrolysis of xylan. Appl Microbiol Biotechnol 100(12):52055214. https://doi.org/10.1007/s00253-016-7555-z

Mullins ED, Chen X, Romaine P, Raina R, Geiser DM, Kang S (2001) Agrobacterium-mediated transformation of Fusarium oxysporum: an efficient tool for insertional mutagenesis and gene transfer. 
Phytopathology 91(2):173-180. https://doi.org/10.1094/Phyto. 2001.91.2.173

Nelson N (1944) A photometric adaptation of the Somogyi method for the determination of glucose. J Biol Chem 153(2):375-380

Numan MT, Bhosle NB (2006) $\alpha$-L-arabinofuranosidases: the potential applications in biotechnology. J Ind Microbiol Biotechnol 33(4): 247-260. https://doi.org/10.1007/s10295-005-0072-1

Pitkanen L, Virkki L, Tenkanen M, Tuomainen P (2009) Comprehensive multidetector HPSEC study on solution properties of cereal arabinoxylans in aqueous and DMSO solutions. Biomacromolecules 10(7):1962-1969. https://doi.org/10.1021/ bm9003767

Ravn JL, Glitsø V, Pettersson D, Ducatelle R, Van Immerseel F, Pedersen NR (2018) Combined endo- $\beta$-1,4-xylanase and $\alpha$-Larabinofuranosidase increases butyrate concentration during broiler cecal fermentation of maize glucurono-arabinoxylan. Anim Feed Sci Technol 236:159-169. https://doi.org/10.1016/j.anifeedsci. 2017.12.012

Saha BC (2000) $\alpha$-L-arabinofuranosidases: biochemistry, molecular biology and application in biotechnology. Biotechnol Adv 18(5):403423. https://doi.org/10.1016/S0734-9750(00)00044-6

Sakamoto T, Ogura A, Inui M, Tokuda S, Hosokawa S, Ihara H, Kasai N (2011) Identification of a GH62 $\alpha$-L-arabinofuranosidase specific for arabinoxylan produced by Penicillum chrysogenum. Appl Microbiol Biotechnol 90:137-146. https://doi.org/10.1007/s00253010-2988-2

Sakamoto T, Inui M, Yasui K, Hosokawa S, Ihara H (2013) Substrate specificity and gene expression of two Penicillium chrysogenum $\alpha$ L-arabinofuranosidases (AFQ1 and AFS1) belonging to glycoside hydrolase families 51 and 54. Appl Microbiol Biotechnol 97(3): 1121-1130. https://doi.org/10.1007/s00253-012-3978-3

Santos CR, Polo CC, Costa MC, Nascimento AF, Meza AN, Cota J, Hoffmam ZB, Honorato RV, Oliveira PS, Goldman GH, Gilbert HJ, Prade RA, Ruller R, Squina FM, Wong DW, Murakami MT (2014) Mechanistic strategies for catalysis adopted by evolutionary distinct family 43 arabinanases. J Biol Chem 289(11):7362-7373. https://doi.org/10.1074/jbc.M113.537167

Sarch C, Suzuki H, Master ER, Wang W (2019) Kinetics and regioselectivity of three GH62 $\alpha$-L-arabinofuranosidases from plant pathogenic fungi. Biochim Biophys Acta Gen Subj 1863(6):1070-1078. https://doi.org/10.1016/j.bbagen.2019.03.020

Shi H, Zhang Y, Li X, Huang YJ, Wang LL, Wang Y, Ding HH, Wang F (2013) A novel highly thermostable xylanase stimulated by $\mathrm{Ca}^{2+}$ from Thermotoga thermarum: cloning, expression and characterization. Biotechnol Biofuels 6:26. https://doi.org/10.1186/1754-68346-26

Shinozaki A, Hosokawa S, Nakazawa M, Ueda M, Sakamoto T (2015) Identification and characterization of three Penicillium chrysogenum $\alpha$-L-arabinofuranosidases (PcABF43B, PcABF51C, and AFQ1) with different specificities toward arabino-oligosaccharides. Enzym Microb Technol 73-74:65-71. https://doi.org/10.1016/j. enzmictec.2015.04.003

Siguier B, Haon M, Nahoum V, Marcellin M, Burlet-Schiltz O, Coutinho PM, Henrissat B, Mourey L, O'Donohue MJ, Berrin JG, Tranier S, Dumon C (2014) First structural insights into $\alpha$-Larabinofuranosidases from the two GH62 glycoside hydrolase subfamilies. J Biol Chem 289(8):5261-5273. https://doi.org/10.1074/ jbc.M113.528133

Sin IN, Perini MA, Martínez GA, Civello PM (2016) Analysis of the carbohydrate-binding-module from Fragaria $x$ ananassa $\alpha$-Larabinofuranosidase 1. Plant Physiol Biochem 107:96-103. https:// doi.org/10.1016/j.plaphy.2016.05.028
St John FJ, Rice JD, Preston JF (2006) Paenibacillus sp. strain JDR-2 and XynA1: a novel system for methylglucuronoxylan utilization. Appl Environ Microbiol 72(2):1496-1506. https://doi.org/10.1128/AEM. 72.2.1496-1506.2006

St John FJ, González JM, Pozharski E (2010) Consolidation of glycosyl hydrolase family 30: a dual domain 4/7 hydrolase family consisting of two structurally distinct groups. FEBS Lett 584(21):4435-4441. https://doi.org/10.1016/j.febslet.2010.09.051

Tang J, Long L, Cao Y, Ding S (2019) Expression and characterization of two glucuronoyl esterases from Thielavia terrestris and their application in enzymatic hydrolysis of corn bran. Appl Microbiol Biotechnol 103(7):3037-3048. https://doi.org/10.1007/s00253019-09662-w

Taylor EJ, Smith NL, Turkenburg JP, D'Souza S, Gilbert HJ, Davies GJ (2006) Structural insight into the ligand specificity of a thermostable family 51 arabinofuranosidase, Araf51, from Clostridium thermocellum. Biochem J 395(1):31-37. https://doi.org/10.1042/ BJ20051780

Thakur A, Sharma K, Goyal A (2019) $\alpha$-L-arabinofuranosidase: a potential enzyme for the food industry. In: Parameswaran B, Varjani S, Raveendran S (eds) Green bio-processes energy, environment, and sustainability. Springer, Singapore, pp 229-244

Tu T, Li X, Meng K, Bai Y, Wang Y, Wang Z, Yao B, Luo H (2019) A GH51 $\alpha$-L-arabinofuranosidase from Talaromyces leycettanus strain JCM12802 that selectively drives synergistic lignocellulose hydrolysis. Microb Cell Factories 18(1):138. https://doi.org/10. 1186/s12934-019-1192-Z

Valls A, Diaz P, Pastor FI, Valenzuela SV (2016) A newly discovered arabinoxylan-specific arabinofuranohydrolase. Synergistic action with xylanases from different glycosyl hydrolase families. Appl Microbiol Biotechnol 100(4):1743-1751. https://doi.org/10.1007/ s00253-015-7061-8

Wang W, Mai-Gisondi G, Stogios PJ, Kaur A, Xu X, Cui H, Turunen O, Savchenko A, Master ER (2014) Elucidation of the molecular basis for arabinoxylan-debranching activity of a thermostable family GH62 $\alpha$-L-arabinofuranosidase from Streptomyces thermoviolaceus. Appl Environ Microbiol 80(17):5317-5329. https://doi.org/10.1128/AEM.00685-14

Wilkens C, Andersen S, Dumon C, Berrin JG, Svensson B (2017) GH62 arabinofuranosidases: structure, function and applications. Biotechnol Adv 35(6):792-804. https://doi.org/10.1016/j. biotechadv.2017.06.005

Yang JY, Zhang Y (2015) I-TASSER server: new development for protein structure and function predictions. Nucleic Acids Res 43(W1): W174-W181. https://doi.org/10.1093/nar/gkv342

Yang W, Bai Y, Yang P, Luo H, Huang H, Meng K, Shi P, Wang Y, Yao B (2015) A novel bifunctional GH51 exo- $\alpha$-L-arabinofuranosidase/ endo-xylanase from Alicyclobacillus sp. A4 with significant biomass-degrading capacity. Biotechnol Biofuels 8:197. https:// doi.org/10.1186/s13068-015-0366-0

Zheng F, Liu J, Basit A, Miao T, Jiang W (2018) Insight to improve $\alpha$-Larabinofuranosidase productivity in Pichia pastoris and its application on corn stover degradation. Front Microbiol 9:3016. https://doi. org/10.3389/fmicb.2018.03016

Zhou X, Li W, Mabon R, Broadbelt LJ (2017) A critical review on hemicellulose pyrolysis. Energy Technol-Ger 5(1):52-79. https:// doi.org/10.1002/ente.201600667

Publisher's note Springer Nature remains neutral with regard to jurisdictional claims in published maps and institutional affiliations. 